\title{
Ixodes ricinus and its transmitted pathogens in urban and peri-urban areas in Europe: new hazards and relevance for public health
}

\section{Annapaola Rizzoli ${ }^{1}$, Cornelia Silaghi ${ }^{2,3}$, Anna Obiegala ${ }^{2,4}$, Ivo Rudolf ${ }^{5}$, Zdeněk Hubálek ${ }^{5}$, Gábor Földvári ${ }^{6}$ Olivier Plantard ${ }^{78}$, Muriel Vayssier-Taussat ${ }^{9}$, Sarah Bonnet ${ }^{9}$, Eva Špitalská ${ }^{10}$ and Mária Kazimírová ${ }^{11}{ }^{*}$}

1 Fondazione Edmund Mach, Research and Innovation Centre, San Michele all'Adige, Trento, Italy

${ }^{2}$ Comparative Tropical Medicine and Parasitology, Ludwig-Maximilians-Universität, Munich, Germany

${ }^{3}$ Vetsuisse-Faculty, Swiss National Centre for Vector Entomology, Institute for Parasitology, University of Zurich, Zürich, Switzerland

${ }^{4}$ Institute of Animal Hygiene and Veterinary Public Health, University of Leipzig, Leipzig, Germany

${ }^{5}$ Institute of Vertebrate Biology, Academy of Sciences of the Czech Republic, v.v.i., Brno, Czech Republic

${ }^{6}$ Department of Parasitology and Zoology, Faculty of Veterinary Science, Szent István University, Budapest, Hungary

7 INRA, UMR1300 BioEpAR, Nantes, France

${ }^{8}$ LUNAM Université, Oniris, Ecole nationale vétérinaire, agroalimentaire et de l'alimentation Nantes-Atlantique, UMR BioEpAR, Nantes, France

${ }^{9}$ USC BIPAR, INRA, ANSES - French Agency for Food, Environmental and Occupational Health and Safety, Maisons-Alfort, France

${ }^{10}$ Institute of Virology, Slovak Academy of Sciences, Bratislava, Slovakia

$"$ Institute of Zoology, Slovak Academy of Sciences, Bratislava, Slovakia

\section{Edited by:}

Juan-Carlos Navarro, Universidad Central de Venezuela, Venezuela

\section{Reviewed by:}

Andrei Daniel Mihalca, University of Agricultural Sciences and Veterinary Medicine Cluj-Napoca, Romania Juan-Carlos Navarro, Universidad Central de Venezuela, Venezuela

*Correspondence:

Mária Kazimírová, Institute of Zoology, Slovak Academy of

Sciences, Dúbravská cesta 9

Bratislava 845 06, Slovakia

e-mail:maria.kazimirova@savba.sk
Tick-borne diseases represent major public and animal health issues worldwide. Ixodes ricinus, primarily associated with deciduous and mixed forests, is the principal vector of causative agents of viral, bacterial, and protozoan zoonotic diseases in Europe. Recently, abundant tick populations have been observed in European urban green areas, which are of public health relevance due to the exposure of humans and domesticated animals to potentially infected ticks. In urban habitats, small and medium-sized mammals, birds, companion animals (dogs and cats), and larger mammals (roe deer and wild boar) play a role in maintenance of tick populations and as reservoirs of tick-borne pathogens. Presence of ticks infected with tick-borne encephalitis virus and high prevalence of ticks infected with Borrelia burgdorferi s.l., causing Lyme borreliosis, have been reported from urbanized areas in Europe. Emerging pathogens, including bacteria of the order Rickettsiales (Anaplasma phagocytophilum, "Candidatus Neoehrlichia mikurensis," Rickettsia helvetica, and R. monacensis), Borrelia miyamotoi, and protozoans (Babesia divergens, B. venatorum, and $B$. microti) have also been detected in urban tick populations. Understanding the ecology of ticks and their associations with hosts in a European urbanized environment is crucial to quantify parameters necessary for risk pre-assessment and identification of public health strategies for control and prevention of tick-borne diseases.

Keywords: ticks, Ixodes ricinus, tick-borne pathogens, urban habitats, Europe

\section{INTRODUCTION}

Tick-borne infections are arthropod-borne diseases frequently reported worldwide. Ticks are known to transmit a great variety of pathogenic agents producing the highest number of human disease cases compared to other vector-borne diseases in Europe $(1,2)$. In general, the eco-epidemiology of zoonotic vector-borne diseases is very complex. It depends on the interactions of the vectors with the reservoir hosts and the pathogenic agents, which are modulated by several abiotic and biotic factors that vary in space and time. Certain tick-borne infections have recently been emerging in new regions or re-emerging within endemic sites and create an increasing concern for public health, food security, and biodiversity conservation (3-5). Global warming obviously affects the spread of tick-borne diseases, but climate alone does not determine the geographical distribution of tick species, their population densities and dynamics, the likelihood of their infection with microorganisms pathogenic for humans and animals, nor the frequency of contacts of humans and domestic animals with infected ticks $(4,6,7)$. Socio-demographic factors, agricultural and wildlife management, deforestation and reforestation, are known to exert a big impact on the transformation of biotopes, thus affecting tick host assemblages as well as tick infection rates (8-10).

Urbanization as one of the socio-demographic factors has increased worldwide in recent decades $(11,12)$. Currently, more than half of the world's population lives in urban areas, and it is expected that 70\% will live in urban areas by 2050 (13). Nowadays, more than $75 \%$ of Earth's ice-free lands show evidence of alteration as a result of human residence and land use, with less than a quarter remaining as wildlands. Europe shows the highest level of urbanization worldwide (14). Urbanization, due to restriction of natural areas, is known to dramatically change the composition of wildlife communities and affect the associated tick populations. In European cities, public parks, gardens, peri-urban 


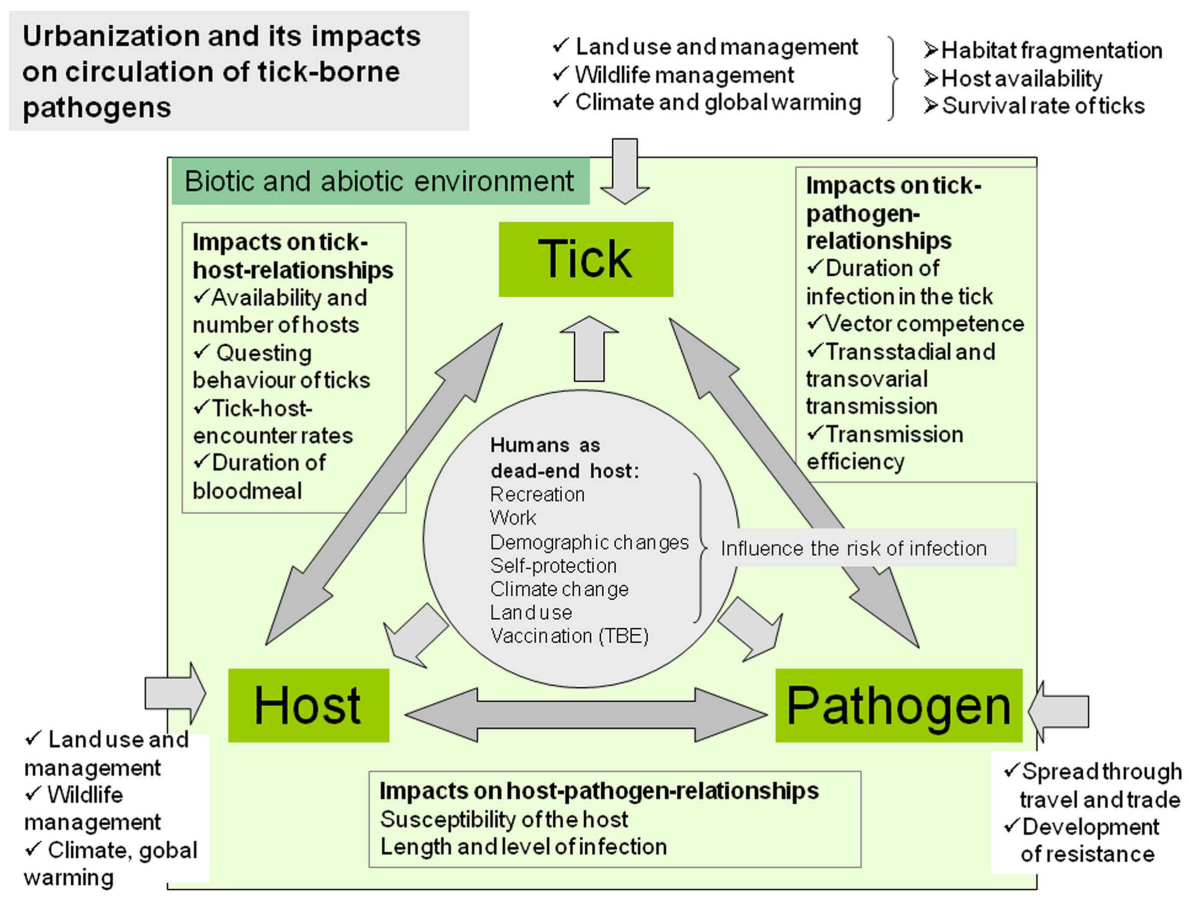

FIGURE 1 | Complex factors of the biotic and abiotic environment influence the tick-host-pathogen interaction and consequently the occurrence of tick-borne diseases in urban and peri-urban environments

leisure-time areas, and cemeteries became particularly important places where humans and domesticated animals can encounter potentially infected questing ticks (2).

Urban areas are highly fragmented environments composed of a mosaic of patches of various sizes, vegetation, and land-use types. Urban and peri-urban habitats are generally characterized by lower biodiversity of wildlife species compared to natural ecosystems. Urbanization often produces a certain gradient of homogenization in densely built-up areas, where synanthropic species adapted to urban habitats can be found and where species richness is reduced (15). On the other hand, suburban habitats are also occupied by native species comprising medium-sized mammalian predators and ground-foraging, omnivorous, and frugivorous birds that produce abundant populations there. But urbanization can also result in variation of animal species composition, e.g., by introduction of non-native species that replace native ones $(16,17)$.

Majority of the wildlife species commonly found in urban and peri-urban sites can serve as tick-maintenance hosts and also as reservoirs of tick-borne pathogens $(18,19)$. Furthermore, the majority of these species are generalists and are able to adapt to the urban and peri-urban environment and reach higher population densities than in natural sites $(12,20,21)$. In urban habitats of Europe, rodents (mice, voles, dormice, squirrels, and rats), hedgehogs, shrews, birds, lizards, and companion animals (dogs and cats), but in peri-urban areas also medium-sized and larger mammals like foxes, roe deer, and wild boars, play the major role as tick-maintenance hosts and reservoirs of tick-borne pathogens
$(19,22)$. Adaptation of wild animals to urban environment can also lead to increased contacts with humans and to increased risk of exposure to zoonotic agents. In addition, animal populations in urban areas can show genetic differentiation from wild populations of the same species. Thus urbanization can alter the biology and population densities of ticks and hosts and may lead to increased transmission of pathogens between vectors and urban-adapted hosts $(11,23)$. Moreover, urbanization is followed by increased mobility of humans, intensive long-distance trade, and new contacts of humans and companion animals with nature, which may contribute to changing of epidemiological and epizootiological conditions in urban and peri-urban areas (12) (Figure 1).

Understanding the ecology of ticks and their association with various hosts in a changing urban and peri-urban European environment is therefore crucial to quantify various parameters necessary for the risk pre-assessment and for the identification of the best public health strategies for tick-borne disease management and prevention. The cascade of events including fluctuations in wildlife community composition and abundance, tick density and emergence, and spread of tick-borne pathogens in various habitat types in Europe are now being modeled as part of the EU FP7 project EDENext ${ }^{1}$. In this review, we focus on Ixodes ricinus, one of the principal vectors of pathogens causing arthropod-borne infections in Europe, its associations with hosts and pathogens and risk of infection of humans in urbanized areas.

\footnotetext{
${ }^{1} \mathrm{http}: / /$ www.edenext.eu
} 


\section{IXODES RICINUS - VECTOR OF MULTIPLE PATHOGENS}

Ixodes ricinus (Acari: Ixodidae) is the most widespread tick species in Europe and transmits several viral, bacterial, and protozoan agents of medical and veterinary importance $(8,24-28)$.

The distribution area of I. ricinus has significantly expanded over the past decades. Recently, the species can be found in more northern areas and habitats at higher altitudes than a few decades ago (29-31). Increase in abundance, habitat expansion, including urbanized areas, and prolongation of the questing activity periods of I. ricinus, reported in recent years, are attributed to multiple and interacting factors $(19,26,32)$. They include changes in land cover and land use due to alterations in agriculture and forestry management, changes in climate, changes in abundance, and distribution of wildlife due to altering wildlife management, and shifts in socioeconomic factors affecting the rate of exposure of humans to infected ticks $(25,26)$.

Risk factors associated with I. ricinus transmissible diseases can be divided generally into: (i) those directly related to climate change (acting on the tick, the host, or their habitats), (ii) those related to changes in the distribution of tick hosts (which may be a direct or indirect effect of human intervention), and (iii) other ecological changes (also commonly influenced by human intervention) (26).

Ixodes ricinus is primarily associated with shrubs and deciduous and mixed forests, with a high abundance of small, medium, and large wild vertebrate hosts. However, as a consequence of changing land use and wildlife management, persistent tick populations and high prevalences of infections with tick-borne pathogens have also been observed in urban and peri-urban sites in many European countries (33-41). Ixodes ricinus is a generalist exophilic tick species that is able to feed on over 300 different vertebrate species (42). It has a long-lasting life cycle, involving three active life stages (larvae, nymphs, and adults) that quest and attach to a host and feed on blood for a few days before detachment (parasitic life period) and subsequent molting or laying eggs (females). Each developmental stage requires its specific microhabitat comprising various biotic and abiotic factors. The parasitic on-host life of I. ricinus is limited to $3-5$ days (larvae), $4-7$ days (nymphs), and 7-11 days (females) of feeding on vertebrate hosts, whereas, the non-parasitic off-host life period of all developmental stages can last for several months or years (43). This extremely complex life cycle makes the tick vulnerable to alterations in habitat structure and availability of host animals.

In urban and peri-urban areas, the requirement for high relative humidity (above $80 \%$ ) for extended periods of time by the off-host stages restricts the occurrence of I. ricinus to city parks with litter layers, forest patches, gardens, and cemeteries (22) where the continuous use of water to maintain the vegetation also increases the relative humidity. The other limiting biotic factor for I. ricinus in urban environments is the availability of medium-sized and large mammals as hosts of the adults, maintaining persistent and independent tick populations. Shifts in the tick-host associations to, e.g., hedgehogs, foxes, hares, domestic dogs, or cats, due to lack of large mammalian hosts can evoke changes in I. ricinus-borne pathogen spectrum, prevalence, and distribution. On the other hand, populations of large animals like deer and wild boar have become more abundant in large city parks and peri-urban areas around European cities, leading to the establishment of tick populations, shift of natural transmission cycles of some pathogens, and increase of the disease risk for humans and domestic animals (19).

\section{VERTEBRATE HOSTS OF TICKS AND TICK-BORNE PATHOGENS IN URBAN AREAS}

Terrestrial vertebrate hosts are key players in the epidemiology of tick-borne diseases for at least two reasons. Firstly, they serve as maintenance hosts for ticks as a food resource and secondly, as reservoir hosts they are often responsible for the long-term maintenance of pathogens in both natural and urban habitats. Although many reports exist about the presence of pathogens in various hosts or ticks removed from them, the reservoir capacity for each of the pathogens in many cases remains to be experimentally defined. A reservoir host of tick-borne pathogens must fulfill certain criteria: (i) it must feed infected vector ticks, at least occasionally; (ii) it must take up a critical number of infectious agents during an infectious tick bite; (iii) it must allow the pathogen to multiply and to survive in at least certain parts of its body; and last but not least (iv) the pathogen has to find its way into other feeding ticks $(44,45)$. For this reason, the simple recording of pathogens (or nucleic acid of them) in a vertebrate host is not sufficient for classifying that host as a reservoir, but only a candidate reservoir when physiological and behavioral features may theoretically support pathogen amplification and transmission to the vector, or a simple carrier host, or a dead end host. Similarly, a higher prevalence in ticks removed from the vertebrate host compared to prevalence in questing ticks is only a good indication that the host is a candidate reservoir. However, to unambiguously prove the reservoir status of a host, xenodiagnostic experiments have to be carried out. They involve feeding of specific pathogen-free tick larvae from a laboratory colony on the tested host and the subsequent analysis of them for pathogens after their molt into the next stage. Unfortunately, for most pathogens and hosts, xenodiagnostic experiments have not been performed so far and the key hosts in the natural (and urban) cycle of tick-borne pathogens remain to be tested. The few exceptions are some species of mice, voles, rats, dormice, squirrels, and shrews (see details in Table 1) that had already been proven reservoirs of some tick-borne pathogens.

Urban environments represent many special ecological characters in the complex communities of pathogens, ticks, and hosts. From a public and veterinary health perspective, city parks and peri-urban recreational areas are typical meeting places for humans (their pets) and ticks. Ticks in this respect serve as a bridge for pathogens, connecting reservoir hosts with humans. In addition to the frequent and likely encounter of humans with ticks, vertebrate host communities also differ substantially in many urban habitats compared to natural settings. Some important tickmaintenance and pathogen reservoir hosts (e.g., hedgehogs, squirrels, and songbirds) have no or very few natural enemies within urban environments, thus their populations might reach significantly higher densities compared to natural ones $(21,74)$. Besides the lack of predators, these urbanized vertebrates can also make use of man-made structures and anthropogenic food resources, like waste and pet food. Hedgehogs are one of the most successful urban adapters reaching up to nine times higher densities in urban areas than in rural areas (74). In Great Britain, red fox density was 
Table 1 | Most important mammal hosts of $I$. ricinus and pathogens transmitted by this tick species with urban or peri-urban occurrence.

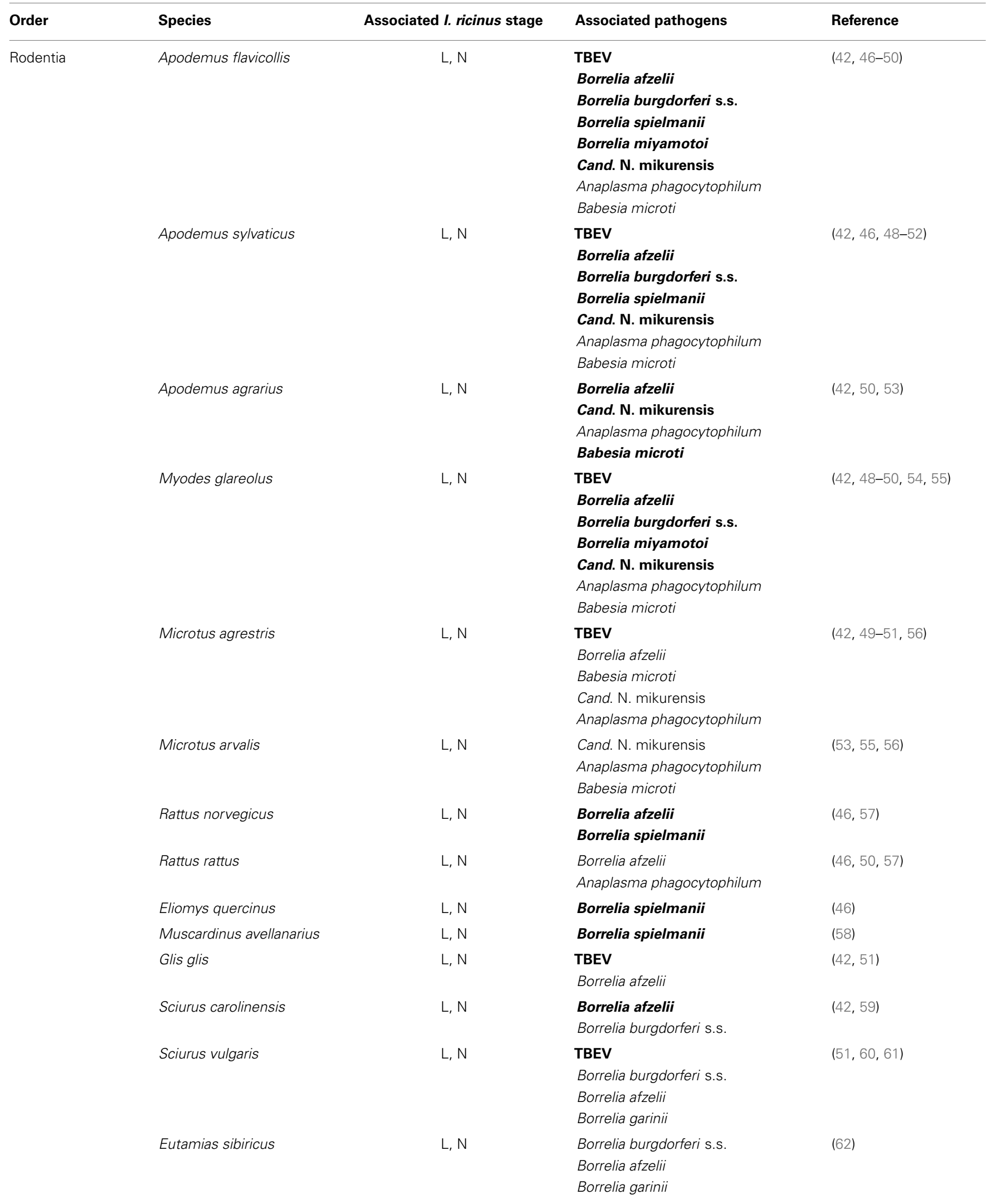


Table 1 | Continued

\begin{tabular}{|c|c|c|c|c|}
\hline Order & Species & Associated $I$. ricinus stage & Associated pathogens & Reference \\
\hline \multirow[t]{2}{*}{ Soricomorpha } & Sorex araneus & $L, N$ & $\begin{array}{l}\text { TBEV } \\
\text { Borrelia burgdorferi s.I. } \\
\text { Anaplasma phagocytophilum } \\
\text { Babesia microti }\end{array}$ & $(49-51,63)$ \\
\hline & Sorex minutus & $L, N$ & Borrelia burgdorferi s.l. & (63) \\
\hline Erinaceomorpha & Erinaceus europaeus & $L, N, A$ & $\begin{array}{l}\text { Borrelia afzelii } \\
\text { Borrelia spielmanii } \\
\text { Borrelia bavariensis } \\
\text { Anaplasma phagocytophilum }\end{array}$ & (64-68) \\
\hline \multirow[t]{3}{*}{ Artiodactyla } & Capreolus capreolus & $L, N, A$ & $\begin{array}{l}\text { Anaplasma phagocytophilum } \\
\text { Babesia venatorum }\end{array}$ & (70) \\
\hline & Cervus elaphus & $L, N, A$ & Anaplasma phagocytophilum & (71) \\
\hline & Dama dama & $L, N, A$ & Anaplasma phagocytophilum & (71) \\
\hline \multirow[t]{2}{*}{ Carnivora } & Vulpes vulpes & $L, N, A$ & $\begin{array}{l}\text { Borrelia burgdorferi s.I. } \\
\text { Anaplasma phagocytophilum }\end{array}$ & $(42,72)$ \\
\hline & Meles meles & $L, N, A$ & $\begin{array}{l}\text { Borrelia afzelii } \\
\text { Borrelia valaisiana }\end{array}$ & (73) \\
\hline
\end{tabular}

Mammal species that are experimentally proven reservoirs for pathogens are in bold. Borrelia burgdorferi s.l. refers to studies with no species identification (genotyping) of the spirochetes. L, larva; N, nymph; $A$, adult.

found at least 10-fold higher in cities than in rural areas $(75,76)$. The tendency to preserve green spaces inside cities is not only a positive aspect to humans but also for many tick-maintenance and reservoir hosts (12). For these urban dwellers, well established and dense shrubbery in parks offers shelter and nest sites. Furthermore, higher temperatures, especially during winter (heat island effect), are highly beneficial (74). All these factors can lead to an unbalanced vertebrate community that easily provides favorable ecological conditions for tick and pathogen cycles.

\section{MAMMALS}

Rodents are among the most important maintenance hosts for the subadult stages of I. ricinus (77). Furthermore, as pointed out by a recent analysis (78), ecologically widespread, synanthropic species with high density and fast life history such as rodents are often the most competent reservoirs for multi-host pathogens. As a consequence, mice and voles are also known to be important reservoirs for several pathogenic agents like tickborne encephalitis virus (TBEV), Borrelia afzelii, and "Candidatus Neoehrlichia mikurensis" (Table 1). In addition to well-established rodent populations in cities, the frequent migration of these animals between human dwellings and natural environments can easily bring infected larvae and nymphs of I. ricinus into gardens and houses (79). Fluctuations in rodent densities are very important factors of disease risk $(24,80)$ with different ecological factors affecting rodent population dynamics in different parts of Europe. However, rodent population dynamics are less studied in urban and peri-urban parks than in natural areas. Rodents can harbor different endophilic (nidicolous) tick species (e.g., Ixodes trianguliceps and I. acuminatus). These do not pose a direct human hazard since they do not feed on humans. Their co-occurrence with $I$. ricinus on the same rodent, however, can lead to an exchange of pathogens among different tick species.

Little is known about the role of rats (Rattus rattus and $R$. norvegicus) in the urban maintenance of ticks and tick-borne pathogens. As one of the most efficient urban adapters, despite the control actions usually undertaken, they might be involved in the urban maintenance of Lyme borreliosis (LB) spirochetes (46, $57,77)$. Other urbanized rodents, like garden dormice (Eliomys quercinus), hazel dormice (Muscardinus avellanarius) $(46,58)$ and hedgehogs (Erinaceus europaeus in Western Europe and E. roumanicus in Central and Eastern Europe) are also involved in the urban ecology of LB (Table 1). Hedgehogs have not only a longer life span compared to rodents but they also have the great 
advantage for ticks being able to feed not only larvae and nymphs but also a considerable number of adults $(21,81)$. Thus, they can easily maintain stable $I$. ricinus populations in urban areas in the long run (64).

In some cases, anthropogenic introduction of mammals into a new area can lead to the emergence of tick-borne pathogens even previously unknown for that region (12). The gray squirrel (Sciurus carolinensis) is native to North America, but an invasive species in the UK that has spread across the country and has largely displaced the native red squirrel ( $S$. vulgaris). This species is a frequent urban dweller and can be an indirect source of human tick-borne infections since it has been experimentally shown to be reservoir for B. afzelii (59). Siberian chipmunks (Eutamias sibiriCus) appeared as pets in many European countries but soon these rodents were recorded in urban parks of Rome (82, 83), Geneva (84), Brussels, and in and around many other towns (12). Chipmunks seem to be perfect hosts for subadult I. ricinus (85). Pisanu et al. (86) showed that these introduced rodents are more heavily infested by $I$. ricinus than native rodents such as the wood mouse (Apodemus sylvaticus) and the bank vole (Myodes glareolus). It was also found that the introduced rodent is associated with three species of B. burgdorferi sensu lato (s.l.), whereas, the native rodents are associated with only one species (62).

Lagomorphs (hares and rabbits) also inhabit anthropogenic landscapes and serve as blood sources for ticks (79). The European hare (Lepus europaeus) and the mountain hare (L. timidus) were shown to be not only effective tick-maintenance hosts but also reservoirs for B. burgdorferi s.l. (63). The European rabbit (Oryctolagus cuniculus) belongs to the most invasive mammalian species and its urban populations can harbor a variety of endoand ectoparasites including I. ricinus (87). These lagomorphs can reach high densities and due to their ability to host adult $I$. ricinus as well, they are able to maintain an infective tick population even in urban and suburban areas where large mammals are not necessarily present. This double epidemiological function (tickmaintenance and reservoir host), which makes them key players in urban cycles of tick-borne pathogens is unique for lagomorphs and hedgehogs.

Bats can also carry different stages of I. ricinus ticks, thus they can also transport ticks to urban areas (88). Species especially adaptive in human dwellings, e.g., the lesser horseshoe bat ( $R h i$ nolophus hipposideros), can serve as tick-maintenance hosts but the role of these flying mammals in the pathogen life cycles remains to be clarified (54). Experimental TBEV viremia was shown in the greater mouse-eared bat (Myotis myotis), which is also a common urban inhabitant (51).

Among larger mammalian hosts, which can affect the circulation of tick-borne pathogens in peri-urban areas, roe deer (Capreolus capreolus), wild boar (Sus scrofa), and red foxes (Vulpes vulpes) are particularly important, because they can host all three active life stages of $I$. ricinus, and they increasingly live in urbanized areas $(89,90)$. Studies on roe deer abundance and movements can provide critical information for predicting tick dispersal and TBEV hazard $(91,92)$. Deer density is also suggested to be related to the LB incidence (31).

Tick density can be influenced by abundance and distribution of roe deer and red deer (Cervus elaphus) (93-95). Roe deer and red deer can inhabit a great variety of tick-infested habitats. Roe deer can even occur in some city parks, e.g., in Munich, Germany (70). Furthermore, the ability of deer to migrate more than $100 \mathrm{~km}$ carrying a high number of ticks is also known. This may facilitate the spreading of ticks to other areas $(95,96)$ and therefore potentially also of tick-borne pathogens from one area to another, although for some pathogen such as Borrelia spp., these species dilute the infection rate (97).

Wild boar populations have increased in Europe in recent decades and these animals are well adapted to live in urban and suburban forest areas (98). This species can provide a significant contribution to maintaining tick populations, although its role of reservoir of various tick-borne pathogens is only partially known $(98,99)$.

Foxes inhabit most urban areas across Europe and population increases have been seen in many European countries, e.g., in Great Britain and Switzerland $(100,101)$. In a recent study, I. ricinus was the most frequently detected tick on foxes in Germany, and all stages of this tick species were found on the animals (90). In Romania, I. ricinus infested almost $30 \%$ of foxes, indicating that these animals may play a significant role in the epidemiology of tick-borne diseases (102).

Urbanization largely concentrates humans in an area as well as a high number of pets (12). Among these, stray dogs represent an especially effective host for ticks, many of which are I. ricinus adults (103). They not only roam in large areas connecting natural and urban habitats, but they also get minimal or no treatment against ticks. Although we have limited knowledge on dogs' role in the maintenance of tick-borne human pathogens (104-106), as effective hosts for $I$. ricinus adults they certainly contribute to the size of tick populations within gardens, parks, and sub-urban areas. The estimated 100 million free roaming dogs (owned and stray) living in Europe (107) certainly need to be taken into consideration during urban surveillance and control of ticks and tick-borne diseases.

\section{BIRDS}

Birds play an important role in the introduction of ticks and associated pathogens into urban areas $(108,109)$. Birds, especially ground-feeding song birds, are important maintenance hosts for larval and nymphal stages of $I$. ricinus. Common urban bird species foraging mostly on the ground and low shrub vegetation, such as common blackbird (Turdus merula), song thrush (Turdus philomelos), and European robin (Erythacus rubecula) were shown to be frequently infested with $I$. ricinus (110-112). More specifically, migratory birds have been shown to carry ticks and pathogens to large distances (113). However, the knowledge on the role of migratory birds in favoring the introduction of ticks and pathogens within new sites is so far very limited (114). Furthermore, earlier onset of spring migration and reproduction with more active ground-feeding activity of birds in the period of questing activities of $I$. ricinus larvae and nymphs may represent an additional risk factor for TBEV spread $(115,116)$. A recent study highlighted that migratory bird species were infested by more ticks than residents, with urbanized birds being the most parasitized (117). Thus in case of cities being close to bird resting or breeding sites (like cities and towns located on river banks) there is a 
realistic chance for the introduction and the maintenance of tickborne pathogens (12). Birds as carriers of infected ticks probably play a role in the geographical spread of pathogens, such as Rickettsia helvetica, Anaplasma phagocytophilum, Babesia microti, and B. venatorum (118-120).

\section{LIZARDS}

Lizards have long been known as important hosts for ticks capable of feeding large amounts of immature I. ricinus (121) and they can often find suitable habitats in cities. In areas inhabited by lizards they can be as important tick-maintenance hosts as rodents $(122,123)$. Compared to rodents, however, lizards are more suitable hosts for nymphal I. ricinus (as shown by a lower larva/nymph ratio) (124-126). Sand lizards (Lacerta agilis), common wall lizards (Podarcis muralis), and green lizards (Lacerta viridis) are the most common species that can contribute to the urban maintenance of $I$. ricinus populations $(122,123,125)$.

The role of lizards in the circulation of tick-borne pathogens has been underestimated compared to that of mammals and birds, but they have been proved to be reservoirs of LB spirochetes (122) and might also be involved in the life cycle of other tickborne pathogens (124). However, experimental and field studies are needed to shed light on this epidemiological issue.

\section{PATHOGENS TRANSMITTED BY IXODES RICINUS}

Among the pathogens transmitted by I. ricinus, the western European TBEV subtype (TBEV-Eur), causing tick-borne encephalitis (TBE) (127) and spirochetes of the B. burgdorferi s.l. complex, the causative agents of human LB (128) have the greatest impact on human health. I. ricinus can also harbor bacteria of the order Rickettsiales that are of rising medical and veterinary importance. Among them, Anaplasma phagocytophilum can lead to granulocytic anaplasmosis in both humans and animals (50); the emerging pathogen "Candidatus Neoehrlichia mikurensis" can cause severe febrile illness in immunocompromised patients (129) and fever in humans without any primary disease (130); rickettsiae of the spotted fever group (SFG) (Rickettsia helvetica, R. monacenis) cause rickettsioses in humans (131). Protozoans of the genus Babesia, mainly $B$. divergens and $B$. microti, cause babesiosis in humans, and for B. venatorum pathogenicity to humans is suspected (132). The role of $I$. ricinus in transmission of Bartonella species (e.g., $B$. quintana and $B$. henselae) causing bartonellosis in humans is suspected $(28,133)$. Francisella tularensis, causing tularemia, and the Q fever agent Coxiella burnetii have also been detected in $I$. ricinus, but the role of this tick species in the epidemiology of these diseases is probably not significant $(28,133)$.

\section{TICK-BORNE ENCEPHALITIS VIRUS}

Tick-borne encephalitis is the most important tick-borne arboviral infection of humans in Europe and eastern and central Asia and is caused by the TBEV (Flaviviridae) (134-136). Ixodes ricinus is the principal vector for the western European (TBEV-Eur) subtype of the virus $(127,137)$. TBE is now endemic in 27 European countries (138) and its expansion northward and into higher altitudes has been observed in recent years $(137,139)$. There is a considerable lack of knowledge in the current fine scale spatial distribution of TBE, including urban areas, thus the risk of infection is still underestimated, especially considering that about two-thirds of human TBE infections are asymptomatic (135).

Incidence of TBE in Europe has been changing in a heterogeneous manner during the last decades, with spatial expansion in some areas and decrease in others (140-142). TBE ecology and epidemiology is expected to be affected considerably by climate change (143) and other drivers like changing in land-use patterns, expansion of forest coverage, increase of abandoned areas, and the creation of new suitable and fragmented landscapes for ticks and hosts within urban areas. Exposure to infected ticks is dependent on several and regionally variable socio-economical factors such as recreational and occupational human activities, public awareness, vaccination coverage, and tourism $(26,94,144)$.

The majority of human TBE infections are acquired through bites of infected ticks, more rarely by the alimentary route through consumption of raw milk of infected goats, sheep, or cattle, or unpasteurized dairy products (145-147). As organic markets become more popular, city dwellers also have to be aware of the TBEV infection risk associated with unpasteurized cow and goat milk and milk products.

Tick-borne encephalitis incidence appears to be increasing, including urban areas, partially as a result of improvements in the diagnosis and reporting of TBE cases, but also due to increased exposure of humans to TBE due to outdoor activities. The risk of exposure to TBE was found to be relatively high even in the immediate surroundings of patients' homes, e.g., in the Czech Republic (148), and an enhanced surveillance of TBE cases in Poland revealed that more than $50 \%$ of patients resided in urban areas (149).

Tick-borne encephalitis virus circulates mainly in natural sylvatic cycles involving vector ticks and reservoir hosts. However, due to expansion of urban sites to previously natural habitats and penetration of small and large wild animals into urban areas, reservoir hosts for TBEV as well as large tick-maintenance hosts can be present also in urban and peri-urban sites and thus ensure circulation of the virus there (150). Ticks remain infected throughout their life and it is suggested that they are not only vectors, but also long-term reservoirs of the virus (151). Rodents (A. flavicollis, A. sylvaticus, M. glareolus, and $M$. arvalis, see Table 1) are important reservoir hosts for TBEV-Eur $(152,153)$ and probably may maintain the virus in nature through latent persistent infection $(154,155)$. Co-feeding tick to tick transmission of TBEV, even in the absence of detectable viremia in these rodent species (156), is crucial to explain the focal distribution of the TBE foci and their potential variation over time (157). Experimental TBEV viremia has been demonstrated also in two lizard species (L. viridis and L. agilis) often occurring in urban areas (51), but field data on their reservoir competence for TBEV are missing. Migratory birds may play an important role in the geographic dispersal of TBEV-infected ticks, which can contribute to the emergence of new foci of disease, including gardens and urban parks, in case abiotic conditions and the vertebrate host spectrum are favorable for the maintenance of the pathogen (158). Among birds, thrushes (Turdus spp.) are the most frequently infested with I. ricinus ticks and also carry the most frequently infected ticks (159), however, the prevalence of TBEV-infected bird-feeding ticks is relatively low. 
Wild and domestic ungulates, carnivores (foxes and dogs), and hares frequently occurring in peri-urban parks and forest patches within urbanized areas, are important actors in the dynamics of TBE, mainly as tick-maintenance hosts and carriers of infected ticks (160-162). Variation in abundance of roe deer was found to considerably affect TBE risk, depending on the threshold densities of tick, rodent, and large vertebrate populations in the area (31, $91,92,163)$. Ungulates probably do not contribute to the amplification of the virus, but may serve as sentinels to identify TBE foci $(163,164)$.

Accompanying dogs also represent an important risk factor for humans to acquire TBE. They are accidental hosts, but can become ill with TBE. In addition, during walking in natural forest or hunting activities, dogs come in contact with infected ticks and can carry them home or to urban parks, where they may later infest humans (165).

In general, data on TBEV prevalence in tick populations and seroprevalence in reservoir and sentinel hosts in urban areas and on the circulation of various virus strains in Europe are scarce (166-169). Furthermore, our knowledge on the mechanism favoring TBEV persistence and amplification in urban sites is very limited. TBEV infection rate in ticks is usually very low $(<1 \%)$ (170-172), but can amount up to $15 \%$ in microfoci (173). TBEVpositive $I$. ricinus ticks have recently been detected, e.g., in a highly urbanized region in Southern Poland (estimated pool prevalence ranging from 0.19 to $1.11 \%$ for positive locations), suggesting the presence of active foci (174). TBEV-infected Dermacentor reticulatus adults were also detected in an urban area (Warsaw) in Poland, with higher prevalence $(3.12 \%)$ than in natural areas. But our knowledge about the importance of this tick species in TBE epidemiology is still limited (175).

Generally, screening of ticks by PCR cannot be recommended for assessment of human TBE risk and alternative methods of environmental TBEV monitoring should be considered, such as serological long-term monitoring of rodents and other wild and domestic animals, which would serve as sentinel species (169).

\section{BORRELIA BURGDORFERI SENSU LATO}

In little more than 30 years, Lyme borreliosis (LB), which is caused by the spirochete $B$. burgdorferi s.l., has risen from relative obscurity to become a global public health problem and a prototype of an emerging pathogen (176). During this period, we have accumulated enormous progress in knowledge of its phylogenetic diversity, molecular biology, genetics, host interactions, pathogenicity for humans as well as other vertebrate species, and preventive measures including vaccine development. But relatively little is known about public health consequences of LB in terms of ecoepidemiology issues and risk of acquiring infection in suburban and urban habitats.

Lyme borreliosis is the most abundant tick-borne disease of humans worldwide, though it only occurs in the northern hemisphere. LB occurs in North America (from the Mexican border in the south to the southern Canadian provinces in the north), the whole Europe, parts of North Africa (Maghreb), and northern Asia (Russian Siberia and the Far East, Sakhalin, Japan, China, and Korea). The geographical distribution of LB correlates closely with the range of the principal vectors, ticks of the I. ricinus complex
(177). LB occurs between approximately $35^{\circ}$ and $60^{\circ} \mathrm{N}$ in Europe, and between $30^{\circ}$ and $55^{\circ} \mathrm{N}$ in North America. In countries at the southern limits of the LB range, its incidence decreases rapidly along the north-to-south gradient (178).

The B. burgdorferi s.l. complex now comprises up to 19 Borrelia species. Of these, only B. afzelii, B. burgdorferi, and B. garinii are proven agents of localized, disseminated, and chronic manifestations of LB in Europe, whereas, B. spielmanii has been detected in early skin disease, and B. bissettii and B. valaisiana have been detected in samples from single cases of $\operatorname{LB}(179,180)$. The clinical role of $B$. lusitaniae remains to be substantiated.

Principal vectors of $B$. burgdorferi s.l. in Europe, including urban and suburban ecosystems, are two tick species: I. ricinus and I. persulcatus, the latter only occurring in eastern and northeastern Europe. Moreover, the occurrence of I. hexagonus in the urban environment, due to the presence of suitable hosts, such as hedgehogs, cats, dogs, and foxes in gardens and public parks, could contribute to transmission of LB (65).

The risk of infection is particularly high in deciduous or mixed forest ecosystems or woodlands, along with city parks and urban gardens, especially gardens close to forests (181). The higher risk of contracting LB in the ecotones between forests and arable fields (178) or meadows, although higher densities of infected vector ticks are within forests, is an effect of frequent human presence along the edges of these habitats (182). Also forest fragmentation in suburban areas theoretically poses a greater risk due to enhanced proportion of ecotones (183). Other risks include reforestation (with increased population of forest rodents, but also deer, the principal host of adult vector ticks). For example, in the Czech Republic Zeman and Januska (184) found that LB risk correlated with overall population density of game (red deer, roe deer, mouflon, and wild boar) regardless of rodent abundance. Nevertheless, increased populations of reservoir hosts (forest rodents) usually stimulate the LB incidence.

All activities that increase human contact with ticks present risk for contracting LB, especially recreational (leisure time) activities in forested and urban areas (jogging, berry/mushroom picking, walking, and hiking), seasonal and occasional living by urban residents in country cottages, mowing and clearing of brush around the home in forested areas and gardening. Ownership of pet dogs and cats could also present a relative risk for humans when the pets are frequently parasitized by ticks and the owner tries to remove the ticks $(178,181)$. Moreover, outdoor employment and work (forestry workers, military personnel in the field, farmers, gardeners, gamekeepers, hunters, and rangers) are at risk. However, in most European countries, occupational exposure generally constitutes only $2 \%$ of LB cases (185), whereas, permanent residence in endemic areas with a high prevalence of infectious ticks (e.g., forested peri-urban areas) is a serious risk factor for LB.

Small rodents (A. sylvaticus, A. flavicollis, and M. glareolus) are regarded as the main reservoir hosts of $\mathrm{LB}$ pathogens in urban and suburban habitats across Europe (Table 1). Garden dormice (E. quercinus) (186) and hazel dormice (M. avellanarius) are especially competent reservoirs of the human pathogenic B. spielmanii $(46,58)$. Important role in the urban maintenance of B. spielmanii and $B$. afzelii could also be played by rats ( $R$. norvegicus and $R$. rattus $)(46,57,187)$. Other key urban players in the maintenance 
of LB spirochetes are hedgehogs (E. europaeus and E. roumanicus) $(64,65,188)$. Red squirrels (S. vulgaris) were found to be heavily infested by ticks and feeding ticks showed high prevalence of infection in enzootic areas in Switzerland (60) and might consequently contribute to maintenance of spirochetes also in urban foci.

Dogs and cats are heavily infested with ticks and might act as hosts (probably not reservoirs) or sentinels for LB. The risk of exposure of dogs to numerous vector-borne pathogens has increased, and close relationship with humans in urban areas poses new concerns for human public health (106).

Ground-foraging bird species such as blackbird (T. merula), song thrush (T. philomelos), robin (E. rubecula), and pheasant (Phasianus colchicus) play a unique role in the epidemiology of LB and also contribute to the transmission cycle of B. burgdorferi s.l. in urban and suburban areas (189-192). Due to their specific immunity (complement system), certain bird species are resistant to some LB spirochetes but susceptible to others (193). They usually carry B. valaisiana and B. garinii and transmit these spirochetes to ticks. In 1998, two xenodiagnostic studies clearly defined the reservoir role of birds in the epidemiology of LB, one on a passerine bird, the blackbird (190), the other on a gallinaceous species, and the pheasant (194). However, the reservoir competence of other bird species needs to be clarified. A recent study showed that circulation of LB spirochetes is partly maintained by bird-specific tick species, and bridged by I. ricinus to other host types (195).

The role of lizards in the maintenance of B. burgdorferi s.l. is still controversial, since several lizard species have been shown to possess a complement with borreliacidal activity (196). However, in some areas LB spirochetes are more prevalent in sand lizards $(L$. agilis) and common wall lizards (P. muralis) than in rodents (122). The lizard-associated LB spirochete is B. lusitaniae, a genospecies previously thought to occur only in Mediterranean and Central Europe (197), but it was shown that it has a far more widespread geographical distribution involving the green lizard (L. viridis), the Balkan wall lizard (Podarcis taurica), and the sand lizard ( $L$. agilis) $(123,125,126)$.

We have reviewed the occurrence of $B$. burgdorferi s.l. in host-seeking urban $I$. ricinus ticks across Europe according to the literature (Table 2). There are also several additional papers demonstrating the presence of borreliae in ixodid ticks collected in (sub) urban areas (198-202). All accessible data show that borreliae in I. ricinus ticks collected in urban parks, gardens, or suburban habitats are prevalent approximately at the same rate as in I. ricinus ticks living in forests (203). In urban areas, therefore the risk of contacting LB could be as high as in natural environment.

We should consider that most studies dealing with ecoepidemiology of LB in patients living in urban areas may have limitation, because not always the exact location (or area) where they acquired the vector tick is known. While popular opinion is that outdoor occupations and hiking are risk activities, several studies have implied that infection is often acquired near the home, during gardening and dog walking associated with increased risk (148, 226-228).

\section{ANAPLASMA PHAGOCYTOPHILUM}

Anaplasma phagocytophilum is a small, gram-negative obligate intracellular alpha-Proteobacterium and infects neutrophilic, eosinophilic granulocytes, and monocytes of mammals. There, it replicates within a cytoplasmatic, cell-membrane derived vacuole. A. phagocytophilum is transmitted by ticks of the I. ricinus complex in the Northern hemisphere and in European countries mainly by I. ricinus (50).

The bacterium has been known since the last century to cause diseases in domestic ruminants (229) and since the 1960s in horses (230). The first human case was described in the USA in 1994 (231). The causative agents of the diseases were at the time classified into the granulocytic group of the genus Ehrlichia, which contained E. phagocytophila as agent of tick-borne fever of ruminants, E. equi as agent of equine granulocytic ehrlichiosis and the human granulocytic ehrlichiosis (HGE)-agent. In 2001, a reorganization of the order Rickettsiales, based on homologies in the $16 \mathrm{~S}$ rRNA gene, reclassified the granulocytic Ehrlichia-group as the new bacterial species $A$. phagocytophilum and the respective diseases were then called granulocytic anaplasmosis (232). Clinical cases are also occurring in dogs and cats, then known as canine and feline granulocytic anaplasmosis $(233,234)$.

After the first cases appeared in the US in the 1990s, human granulocytic anaplasmosis (HGA) has become one of the most important tick-borne diseases in the US, with an incidence in 2010 of 6.1 cases per 1 million inhabitants ${ }^{2}$. The first human case in Europe was described in the 1990s (235), and around 100 cases have been described since then in several European countries, e.g., in Slovenia, Croatia, Czech Republic, Slovakia, Austria, Latvia, the Netherlands, Norway, Poland, Spain, France, and Sweden (236252). Seroprevalence rates in humans in Europe are around 1-20\% and they fluctuate depending on anamnesis, tick exposure, and age of the patients (253).

Mammalian host species (Table 1) such as wild ruminants (e.g., roe deer, red deer, fallow deer, but also mountain ungulates), small mammals such as rodents and insectivores, but also foxes, bears, wild boars, birds, and reptiles are infected with A. phagocytophilum (50). Prevalence rates in wild ruminant species in Europe are generally high, e.g., ranging in roe deer and red deer from around $12 \%$ to over $85 \%(70,254-256)$. On the other hand, prevalence rates in small mammals are from $0 \%$ to about $20 \%$ (50).

Anaplasma phagocytophilum is detected with varying prevalences in questing I. ricinus ticks, and has been found in Europe in nearly 30 countries. The prevalence ranged, for example, in Norway from 0.4 to $17.1 \%$, in Estonia from 3 to $6.5 \%$, in Slovakia from 1.1 to $8.3 \%$, and in Germany from 1.0 to $17.4 \%$ [reviewed in Ref. (50)]. So far, transovarial transmission has not been shown in Ixodes ticks. As such, for the current state of knowledge, a reservoir host is necessary to keep up the endemic life cycle of A. phagocytophilum in nature.

The discrepancy of a high occurrence of A. phagocytophilum in ticks and mammals as well as high seroprevalence rates in Europe in contrast to few clinical cases has been explained by the potential underdiagnosing of the disease, or the potential occurrence of less virulent strains in Europe in comparison to the USA. The discrepancy could also be explained by a higher awareness of US physicians to the disease because in the USA it is a notifiable

\footnotetext{
${ }^{2}$ www.cdc.gov/anaplasmosis
} 
Table 2 | Occurrence of Borrelia burgdorferi sensu lato in questing Ixodes ricinus ticks in urban and suburban areas in Europe.

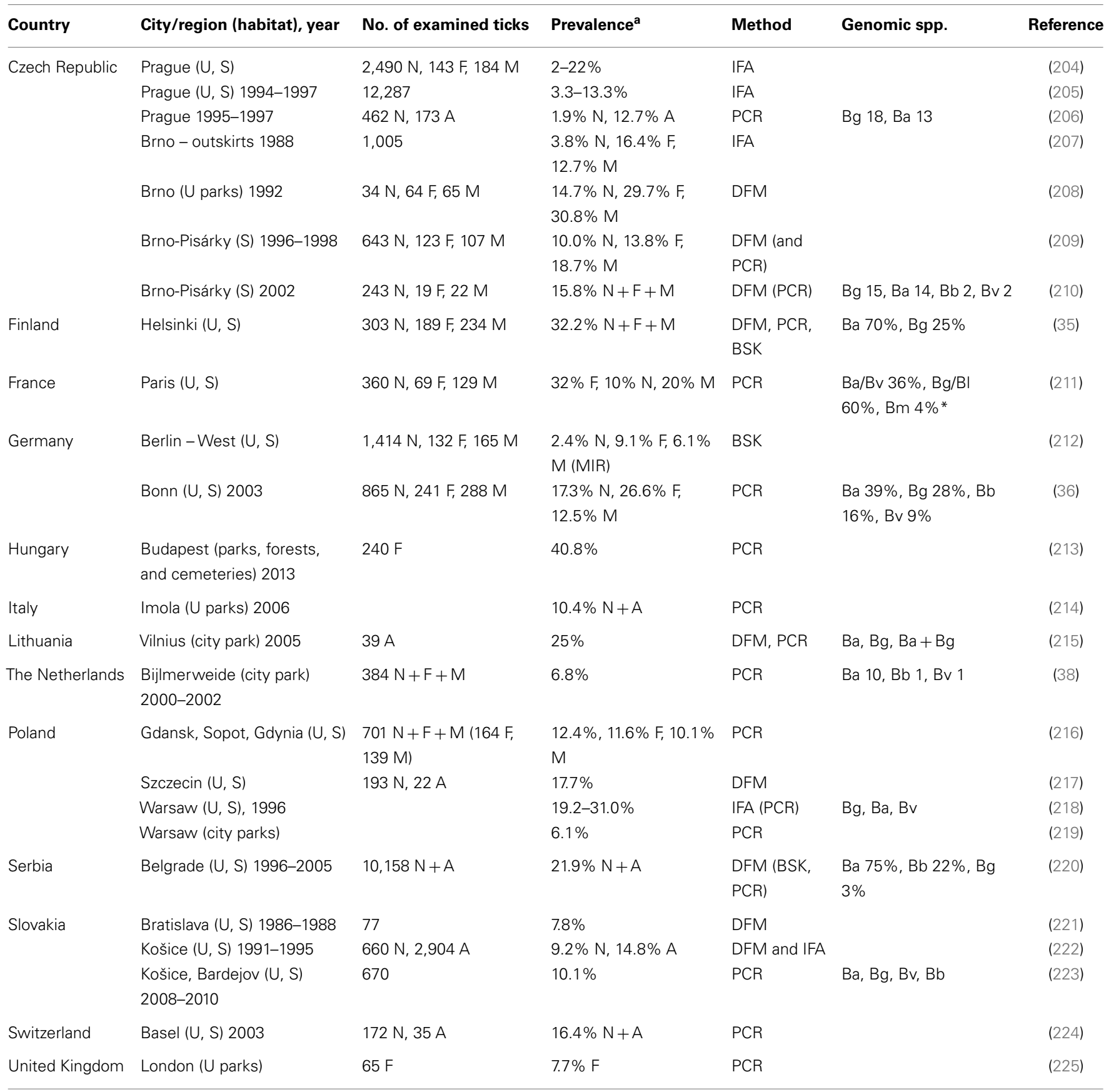

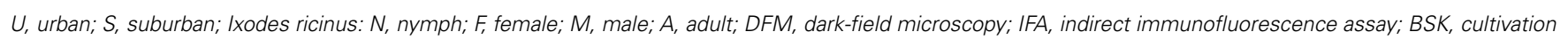
in BSK II medium; Ba, Borrelia afzelii; Bb, B. burgdorferi s.s.; Bg, B. garinii; BV, B. valaisiana; BI, B. lusitaniae; Bm, B. miyamotoi; MIR, minimum infection rate. a Different PCR methods were used that differ in their sensitivity.

*No sufficient discrimination between Bg and Bl and between Ba and Bv.

disease. However, A. phagocytophilum shows also genetic heterogeneity and potential differences concerning the potential host tropisms and pathogenicity (118). A potential human pathogenic strain of A. phagocytophilum in Europe has been especially suspected to be connected with wild boars. This was confirmed in recent studies $(257,258)$.
Several studies have investigated the genetic heterogeneity on the basis of several genes such as $16 S$ rRNA, groEL heat-shock protein, major surface protein coding genes, and the ankA gene $(255,259-261)$. Several distinct clusters were found where, in general, strains derived from domestic animals or ruminants clustered together. Roe deer strains often clustered separately from 
Table 3 | Occurrence of Anaplasma phagocytophilum in questing Ixodes ricinus ticks in urban and suburban areas in Europe ${ }^{a}$

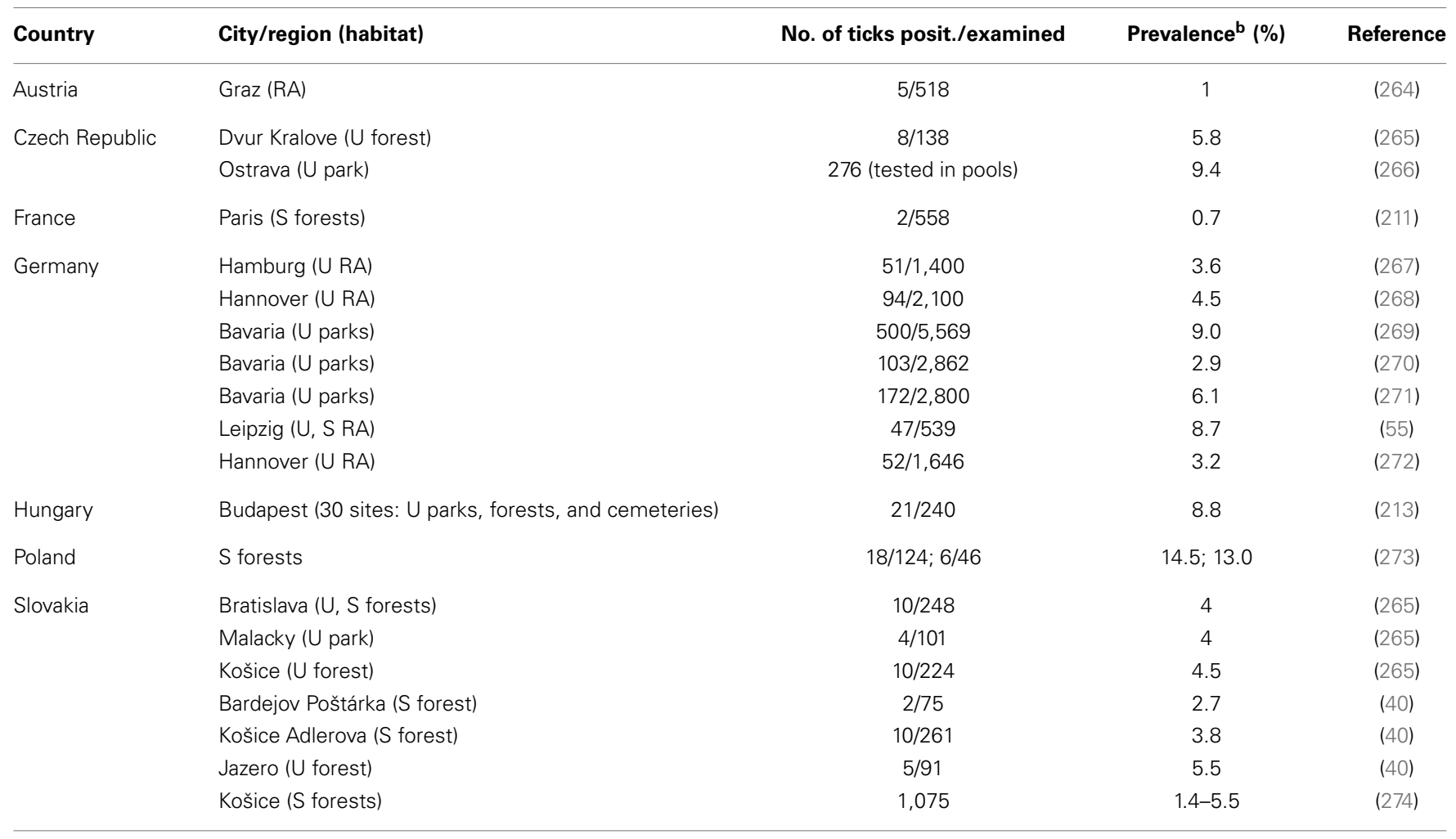

$U$, urban; S, suburban; $R A$, recreational area.

${ }^{a}$ Negative results not shown,

${ }^{b}$ different PCR and real-time PCR methods were used that differ in their sensitivity.

strains derived from other animals. No evidence was found that wild ruminants are involved in the transmission cycles of potentially pathogenic strains. This was shown again by a recent multi locus sequence typing study (262). However, another study found pathogenic strains associated mostly to ungulates (118).

Furthermore, in a recent large-scale analysis, four A. phagocytophilum ecotypes with significantly different host ranges were identified based on groEL heat-shock protein gene sequences of various European vertebrate and tick samples (99). So far, all human cases clustered in ecotype I with the broadest host range (including domesticated animals, red deer, wild boar, and urban hedgehogs). Ecotype II was associated with roe deer and some rodents, ecotype III included only rodents. Birds seem to have a different enzootic cycle from all these (ecotype IV). Based on population genetic parameters, ecotype I showed significant expansion, which might have occurred through an increase in either the population of I. ricinus ticks, or in the (often urban) vertebrate host species, or in both (99).

Only recently, a HGA case of a German patient has been published having acquired the infection whilst on holidays hiking in Scotland (263). This shows that the risk of contracting this infectious agent can also be in leisure time whilst hiking, or even in the cities whilst being in urban or peri-urban park areas.

In about the last 5 years, considerable research effort has been undertaken in Europe to investigate the epidemiology of A. phagocytophilum, especially in urban areas and high prevalences of this pathogen have been found with seasonal and geographic variability. An overview of recent studies investigating questing I. ricinus in urban and suburban areas is shown in Table 3. However, when considering A. phagocytophilum prevalence rates in ticks, the genetic variability has to be taken into account as not all strains may be pathogenic to humans.

\section{CANDIDATUS NEOEHRLICHIA MIKURENSIS}

"Candidatus Neoehrlichia mikurensis" (Candidatus N. mikurensis) is a tick-borne pathogen, which is probably transmitted by $I$. ricinus ticks (24). However, transovarial transmission in this tick species has not been reported yet.

Currently, the genera Wolbachia, Ehrlichia, Neorickettsia, Aegyptianella, and Anaplasma belong to the rickettsial family Anaplasmataceae (232). Most certainly, the new genus "Neoehrlichia" will be included in this family in future. The pathogens of this family are intracellular bacteria transmitted by arthropods and may cause severe diseases in humans and animals. For at least three of the five existing genera within this family (Anaplasma, Ehrlichia, and Neorickettsia) serological cross reactions are not known so far (275). Candidatus N. mikurensis is an obligate intracellular gramnegative bacterium, which is characterized by an endothelial cell tropism but it could not be cultivated in vitro thus far. Therefore, the status "Candidatus" is still preserved.

A previous study published data on not taxonomically grouped Ehrlichia DNA in engorged I. ricinus ticks from roe deer in the 
Table 4 | Occurrence of Candidatus N. mikurensis in questing lxodes ricinus ticks in various habitats in Europe.

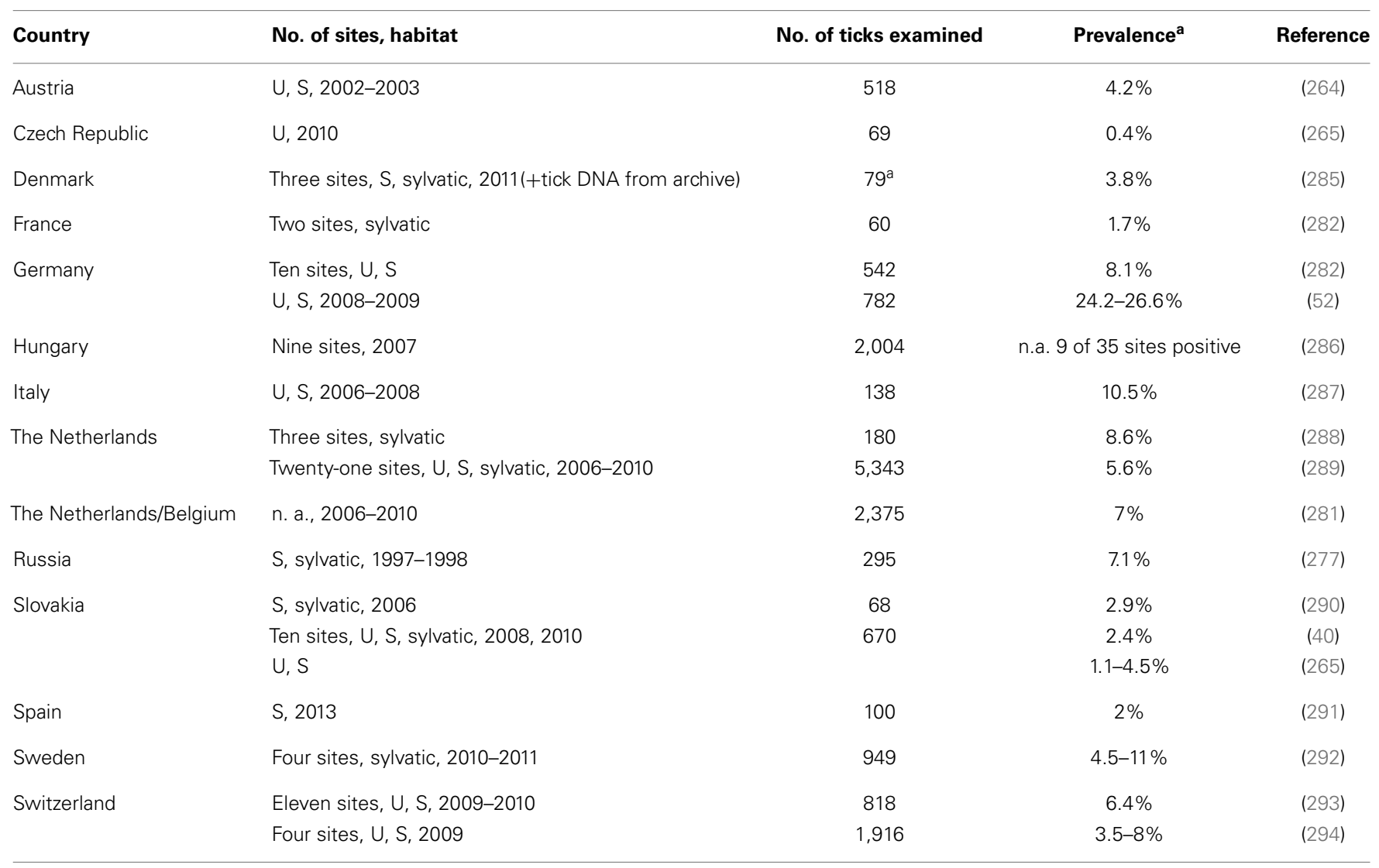

U, urban; S, suburban.

a Different PCR and real-time PCR methods were used that differ in their sensitivity. n.a., not available.

Netherlands (276). This pathogen was then named after the senior author as "Schotti-Variant" (276). Similar sequencing results were published for I. ricinus and I. persulcatus ticks from the Baltics in 2001 (277). Between 1998 and 2001, DNA of a pathogen, suggested to be called Cand. Ehrlichia walkerii spp. nov., was found in engorged $I$. ricinus ticks that fed on asymptomatic patients from Italy (278). In 2003, DNA sequences of this new pathogen were detected in DNA extracted from I. ricinus ticks from Germany, followed by first investigations on possible reservoir hosts (279). In 2003, a pathogen was found via examination by conventional PCR in three wild rats ( $R$. norvegicus) in China. This examination was followed by DNA sequencing of this pathogen, which was then called the "Rattus Variant" (280). In 2004, DNA of this "new" pathogen was found in 7 out of 15 brown rats from a Japanese isle called Mikura (275). The pathogen was passaged in Wistar rats and first investigations on the ultrastructure and the phylogenetic analysis were done, which lead to the currently valid taxonomic denomination "Candidatus Neoehrlichia mikurensis." The close genetic similarity of the $16 S$ rRNA and the groEL gene puts Candidatus N. mikurensis in the family of Anaplasmataceae.

Candidatus N. mikurensis was found widespread in I. ricinus throughout Europe $(281,282)$. It could be detected in Italy, France, Sweden, Russia, and other European countries (Table 4).
The prevalences ranged between 1 and $11 \%$ but focal areas were found with prevalence rates up to $26.6 \%$ (49) (Table 4). Furthermore, Candidatus N. mikurensis was detected in one out of 126 I. ricinus ticks that were collected in Moldavia back in the year 1969 (283) and it was only detected in the genus of Ixodes ticks so far (284). Positive ticks were not only found in sylvatic and nonanthropogenic sites but also in urban and peri-urban sites with human influence in Europe (Table 4).

Previous studies on potential reservoir hosts revealed that rodents, especially bank voles and yellow-necked mice, but also common voles (M. arvalis) were infected at high rates, suggesting a role as reservoir hosts $(52,281,295,296)$, but insectivores were found to be negative for Candidatus N. mikurensis thus far (52). Recently, the reservoir role of Apodemus mice (A. flavicollis and A. sylvaticus) and bank voles (M. glareolus) has unambiguously been proven in a xenodiagnostic study [(48); Table 1]. Urban hedgehogs (E. roumanicus) with high density in a Budapest city park were found to be carriers of Candidatus N. mikurensis, indicating that non-rodent reservoirs might be also involved in the maintenance of this pathogen, especially in human dwellings (69). Additionally, Candidatus N. mikurensis was detected in dogs from Germany and Nigeria $(297,298)$.

In the past, the detection of Candidatus N. mikurensis in rodents and ixodid ticks was an interesting but only incidental 
finding without any medical importance (299). In contrast to this assumption, it was recently found in humans (50) with immune deficiency but without being in an occupation group at risk for tick bites over the last decade. Candidatus N. mikurensis caused unspecific symptoms such as fever, septicemia, malaise, and weight loss in these patients (300-302). Until October 2012, the first six clinical cases of neoehrlichiosis were the only human cases confirmed by laboratory diagnostic methods. All of these patients suffered from a primary disease, were immunocompromised and came from European countries, such as Germany (301), the Czech Republic (303), Sweden (302), and Switzerland (300). Nevertheless a primary disease is not a necessary precondition to develop neoehrlichiosis as Candidatus N. mikurensis could be detected in blood of 7 out of 622 patients from China suffering from fever (130). The authors of these clinical reports emphasize that these seven patients were otherwise healthy and did not suffer from a chronic or immunosuppressive disease. The most recent two human cases were reported in Switzerland, where both patients recovered quickly after a treatment with Doxycycline (294). The data, gained in the last decade, lead to the assumption that Candidatus $\mathrm{N}$. mikurensis is an emerging pathogen that might be found by increasing numbers in ticks from sylvatic and urban sites, in small mammals and humans in future (281, 304). Further investigations are needed on the spread, maintenance, and potential reservoir hosts to assess the risk potential of Candidatus N. mikurensis.

\section{RICKETTSIAE}

Rickettsiae are Gram-negative, obligate, aerobic, intracellular bacterial parasites of eukaryotes that survive freely within the cytosol of the host cell, and belong to the family Rickettsiaceae and order Rickettsiales. Rickettsiae are traditionally subdivided into the typhus and the spotted fever group (SFG). SFG rickettsiae are associated with hard ticks (Ixodidae), with the exception of Rickettsia akari (mite-borne) and R. felis (flea-borne). Hard ticks can transmit them transstadially and transovarially and serve both as vectors and reservoirs of these pathogens. Vertebrates are suspected to serve as reservoirs of rickettsiae, but they may also be accidental hosts and acquire infection by a tick bite (305). However, in a recent xenodiagnostic experiment infected rodents were not able to transmit $R$. helvetica or $R$. monacensis to I. ricinus larvae (48).

In Europe, R. felis, R. typhi, R. prowazekii, R. akari, R. conorii, $R$. slovaca, $R$. sibirica mongolotimonae, $R$. raoultii, $R$. massiliae, $R$. aeschlimanni, $R$. helvetica, and $R$. monacensis have been implicated in human diseases or reported as emerging pathogens or isolated from vectors or humans (131, 306-308). Furthermore, the candidate species "Candidatus Rickettsia kotlanii," "Candidatus Rickettsia barbariae," or "Candidatus Rickettsia vini" have been found in ticks in Europe (309-311). Numerous rickettsiae are regularly associated with ticks and have been called symbionts, microsymbionts, or endosymbionts (living in endocellular symbiosis). However, their potential for pathogenicity is still unknown (312).

The presence of tick-borne rickettsiae has been reported from almost all European countries. The current view on geographic distribution of Rickettsia species in the world is summarized by Parola et al. (131).
In Europe, $I$. ricinus ticks are known to carry mainly $R$. helvetica and $R$. monacensis. However, $R$. massiliae was also detected in $I$. ricinus ticks (313). The following rickettsial genotypes were detected only by molecular tools in I. ricinus ticks collected in Europe: “Candidatus R. vini” was proposed as a new Rickettsia spp. detected in I. arboricola and I. ricinus collected from three different bird species in Spain (311), Rickettsia spp. strain Davousti, previously found in Amblyomma tholloni ticks in Africa, was detected in Ixodes spp. collected from migratory birds in Sweden (314), “Candidatus Rickettsia moreli” (GenBank accession numbers Y08784 and Y08785) was detected in I. ricinus from Spain, and Rickettsia spp. clone KVH-02-3H7 (GenBank accession number GQ849216) was detected in I. ricinus in the Netherlands (131).

Rickettsia helvetica was first isolated from I. ricinus in Switzerland and it was confirmed to be a new member of the SFG rickettsiae in $1993(315,316)$. It has been generally accepted that I. ricinus is the main vector and natural reservoir of $R$. helvetica. However, D. reticulatus ticks were found to be infected with $R$. helvetica in Croatia (317). R. helvetica has been detected in questing and bird-feeding $I$. ricinus ticks in at least 24 European countries (131). The prevalence rates vary from $0.5 \%$ in a bird conservation island named Greifswalder Oie in the Baltic Sea to $66 \%$ in the Netherlands $(318,319)$. For example, the highest infection rate of $R$. helvetica in I. ricinus from Denmark was found in May, followed by July, August, and October (320). The presence of R. helvetica was also confirmed in $I$. ricinus in some urban and peri-urban sites in Slovakia, the Czech Republic, Germany, Portugal, Serbia, and Poland (Table 5).

In 1999, R. helvetica was associated with chronic perimyocarditis in sudden cardiac death in Sweden (328). This species has been cultivated from a patient with subacute meningitis (329). The hypothetical role of $R$. helvetica as an etiological agent of sarcoidosis could not be confirmed (330). The illness is associated with fever, headache, arthralgia, and myalgias and less frequently with rash and/or an eschar $(331,332)$.

Rickettsia monacensis was originally isolated as new species from I. ricinus collected in a city park in Germany (333). Phylogenetic analyses of the $16 S$ rRNA, gltA, and rompA gene sequences demonstrated its close relationship with Candidatus Rickettsia spp. IRS3 and Cand. Rickettsia sp. IRS4 isolated from I. ricinus in north-eastern and south-western Slovakia $(334,335)$. The prevalence rates of $R$. monacensis in $I$. ricinus ticks vary from $0.5 \%$ in Germany to $34.6 \%$ in Turkey $(322,336)$. R. monacensis has been detected in $I$. ricinus ticks in at least 18 European countries (131). The presence of $R$. monacensis was also confirmed in I. ricinus ticks in some urban and peri-urban sites in Slovakia, the Czech Republic, Germany, Portugal, Serbia, and Poland (Table 5). In 2005, $R$. monacensis was identified as a human pathogen in two patients in Spain (in June and September) and latter in one patient in Sardinia, Italy (in April) $(337,338)$. In addition to fever and flulike symptoms, the inoculation eschar was identified in an Italian patient, and a generalized rash including the palms and soles was identified in a Spanish patient.

Rickettsia massiliae was originally isolated from Rhipicephalus sanguineus ticks collected near Marseille, France, in 1992 and then detected in $R$. sanguineus, $R$. turanicus, $R$. pusillus, R. bursa, and I. ricinus ticks in France, Greece, Portugal, Switzerland, Spain, 
Table 5 | Occurrence of Rickettsia spp. in questing Ixodes ricinus ticks in various habitats in Europe.

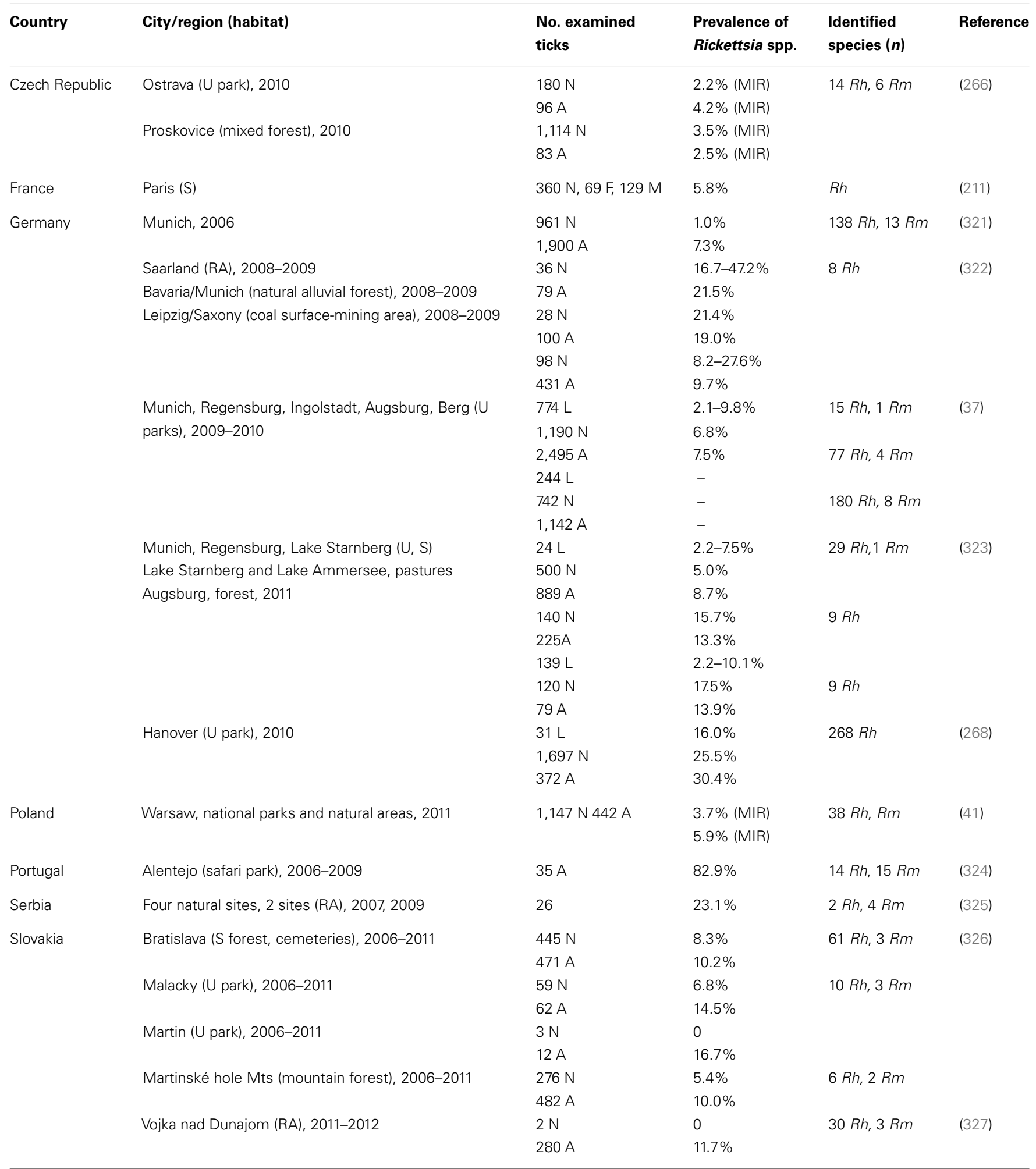

U, urban; $S$, suburban; $R A$, recreational area; Ixodes ricinus: L, larva; N, nymph; $A$, adult; MIR, minimum infection rate; $R$ h, $R$. helvetica; Rm, $R$. monacensis.

including islands: Sardinia and Sicily (Italy), the Canary Islands (Spain), Cephalonia (Greece), and Cyprus (131). R. massiliae was identified in four I. ricinus ticks removed from humans at hospitals in Castilla y León, Spain (313). However, to our knowledge, there are no other studies of this species in urban areas. 


\section{BABESIA}

Ixodes ricinus is the vector of three intraerythrocytic protozoan parasites circulating in Europe and involved in human babesiosis: $B$. divergens, $B$. venatorum (originally designated Babesia spp. EU1), and B. microti. To date, no other Piroplasmida affecting humans have been reported to be transmitted by this tick species, even though it feeds on a very large spectrum of hosts, which are potentially infected by several parasite species including numerous other Babesia species associated to wildlife or domestic animal diseases. However, the list of potential or known tick-borne pathogens is constantly evolving, either due to: (i) the description of Babesia species new for science, (ii) the spread of parasite species previously unknown in Europe, or (iii) the discovery of a Babesia species previously restricted to animals but now known to be associated with humans. Thus, emergence or re-emergence of tick-borne diseases leads to the development of unknown health risks (339). Therefore, there is a real concern that tick-borne diseases due to parasites will appear in areas previously free of such diseases, and there is a real necessity of an epidemiological surveillance of the parasitic communities hosted, and potentially transmitted by ticks (340).

Although best known as an animal disease, babesiosis is a zoonotic disease, classified as emerging by some authors. Approximately 50 human cases of babesiosis have been reported in Europe, which is probably underestimated because of a large proportion of asymptomatic infections, as suggested by seroprevalence studies (341). Among the Babesia species pathogenic for humans, the bovine parasite $B$. divergens is thought to be responsible for most European cases of human babesiosis (342). However, since 2003, cases of human babesiosis have also been attributed to B. venatorum in Austria, Italy, and Germany $(343,344)$ as well as to B. microti in a single case in Germany (341). Whilst the clinical signs of human babesiosis are usually limited to splenectomized patients, two human cases (one attributed to $B$. divergens, the other to an unknown origin) have been detected in immunocompetent patients in eastern France (345). It is also noticeable that, as an example, $0.38 \%$ of the French population is splenectomized (346). Moreover, the rising number of HIV-positive individuals and the increasing population of immunocompromised humans, especially in urban areas, may therefore lead to boost the number of human babesiosis cases (341). The proportion of the population at risk of Babesia infection is thus higher than previously suspected and Babesia spp. likely represents real potential agents of an emerging zoonotic disease and needs increased attention and vigilance.

Besides transstadial transmission, transovarial transmission within ticks is characteristic for most Babesia spp. (differentiating them from Theileria species), which implies that ticks constitute a real parasite reservoir in the field, facilitating the long-term persistence of Babesia species in the ecosystem (sometimes over several tick generations) (347). In Europe, infection rates of Babesia spp. in ticks are usually rather low, but published values range from 0.9 to $20 \%$ (341).

Babesia divergens is a bovine parasite transmitted by I. ricinus, and is thought to be responsible for most cases of human babesiosis in Europe (342). This parasite is the most widespread and pathogenic Babesia species infecting cattle in northern temperate areas (342). Thus, any urban or peri-urban area where cattle and I. ricinus are found is potentially at risk. For example, $B$. divergens has been found in an $I$. ricinus tick collected in an urban park in Germany (37). Recently, the discovery of this parasite in questing I. ricinus from a forest area in Eastern France (340), as well as in I. ricinus collected from wild cervids in Belgium (348), may suggest that its geographical distribution is increasing, even within forested areas without cattle farms, which would require the existence of reservoir hosts other than cattle. Indeed, it was reported that $B$. divergens is also able to infect ungulates (roe deer, fallow deer, red deer, mouflon, and sheep), splenectomized rats, as well as non-splenectomized reindeer, sheep, and gerbil [see review in Ref. (347)]. Thus, this parasite has been shown to have a wider vertebrate host range than previously thought, leading to a potential risk not only in rural areas but also in peri-urban ones.

Babesia venatorum, implicated in human cases of babesiosis in Europe $(343,344)$, seems to phylogenetically lie in a sister group with $B$. divergens (343), and some serological cross-reactivity between $B$. divergens and $B$. venatorum has been reported (349). Roe deer were strongly suspected to be the wildlife reservoir of this parasite $(350,351)$ and its transmission by $I$. ricinus was validated both in vivo $(351,352)$ and in vitro $(353)$. In addition, $B$. venatorum has been identified in I. ricinus in several European countries including Slovenia (354), Switzerland (355), the Netherlands (356), Poland (357), Italy (358), Belgium (359), Germany (37), and France $(211,351)$, with prevalence varying from 0.4 to $1.3 \%$, demonstrating a wide geographical spread across the continent. Increasing reports of $B$. venatorum in ticks and wild ruminants make this parasite an excellent candidate for the emergence of a new zoonotic tick-borne disease, in particular in the current context of a growing number of wild hosts such as deer. As roe deer is often found even in suburban or peri-urban parks (if they are connected to more natural or semi-natural areas such as forests or rural areas), I. ricinus sampled in such places have already been reported as infected by $B$. venatorum $(55,323)$. This parasite has been detected in $1.3 \%$ of questing I. ricinus collected in France in a forest located in the South of Paris metropolitan area in the middle of an urban zone (211). Because of its location and the recreational activities available, this forest is visited by over 3 million people every year, emphasizing the public health risk. Similarly, the first detection of B. venatorum in Poland has been reported from ticks collected in an urban area (357), and a later study performed in recreational areas, corresponding to peri-urban forest near Warsaw city, showed also the presence of $B$. venatorum in questing I. ricinus (360).

Recent molecular phylogenetic investigations have convincingly established B. microti as forming a distinct and early diverging clade relative to other Babesia species (including the clade containing $B$. divergens and B. venatorum) as well as to Theileria species (361-363). B. microti is responsible for several hundred cases reported yearly in the USA in both spleen-intact and asplenic patient (132). This rodent parasite is known to be transmitted by $I$. ricinus, and now seems to be widely established in Europe, although only one human case has been reported to date (341). The substantial difference in the human pathogenicity of the NorthAmerican and European B. microti strains need further studies. It has been identified in $I$. ricinus in several European countries 
such as Switzerland (364), Poland (365), Hungary (366) Slovenia (367), Germany (368), the Netherlands (356, 369), Belgium (359), and France (340). Microtine rodents and probably shrews are the reservoirs of $B$. microti (Table 1 ). Infectious tick bites are most likely to occur in deciduous woodland and peri-domestic settings $(37,55,323)$. Indeed, this parasite was recovered in questing ticks from a forest in Poland that was qualified as "one of the most popular tourist destinations in Poland," highlighting the risk for humans during recreational activities (360).

\section{NEW OR NEGLECTED TICK-BORNE PATHOGENS: STILL UNKNOWN BACTERIAL, PARASITIC, AND VIRAL SPECIES TO BE DISCOVERED?}

Due to advances in molecular biology, new species, strains, or genetic variants of microorganisms are being detected in ticks, resulting in an ever-increasing list of pathogens capable of infecting domesticated animals and humans. Some of them have been linked to human or animal diseases only many years after their first discovery in ticks or animal reservoirs (299). An emblematic example is that of $B$. henselae, the agent of Cat Scratch Disease, known to be transmitted from cat to human by cat scratch (or by fleas). For years, cases of $B$. henselae infection had been described in patients without history of contact with cat without any idea how these people could be infected. By screening pathogens in ticks, B. henselae DNA, and RNA were identified in I. ricinus (370373). After many years of debate to know whether B. henselae was or was not a tick-borne pathogen, the direct link between tick bites, $B$. henselae, and disease in humans was finally demonstrated (374). Another striking example is the one of Borrelia miyamotoi. This Borrelia species has been isolated for the first time in Japan in 1995 from Ixodes ticks and has been considered as nonpathogenic endogenous tick bacteria until the first human cases of B. miyamotoi infection were reported in Russia in 2011 (375). Since then, human infections have been described in the USA and in 2013 in the Netherlands (376-379). In France, B. miyamoto $i$ was found to circulate in $I$. ricinus as well as in the bank vole M. glareolus (380), and this French genotype was identical to the genotype isolated from a sick person in the Netherlands. These findings have important implications for public health, especially considering that $B$. miyamoto $i$-positive ticks and rodents were collected from different sites in close proximity to human dwellings. Up to now, no human cases of $B$. miyamotoi infections have been reported in most European countries, however, symptoms caused by B. miyamotoi could easily be confused with symptoms caused by other pathogens, which are better known by practitioners, suggesting that surveillance urgently needs to be improved.

A more recent example of neglected pathogens is a new phlebovirus that has been described in humans from northwestern Missouri, USA independently presented to a medical facility with fever, fatigue, diarrhea, thrombocytopenia, and leukopenia, and all had been bitten by ticks 5-7 days before the onset of illness. Electron microscopy revealed viruses consistent with members of the Bunyaviridae family. Next-generation sequencing and phylogenetic analysis identified the viruses as novel members of the phlebovirus genus (381). All these examples demonstrate that new or unexpected tick-borne pathogens are characterized, as soon as they are looked for, in patients bitten by ticks.

\section{CONCLUSION}

Tick-borne diseases in urban and peri-urban areas represent a rising hazard for public and animal health in Europe. The rapid global changes that planet Earth is facing, especially due to the human ecological footprint, are also affecting the ecology and epidemiology of infectious diseases, including tick-borne diseases. The $I$. ricinus tick being the principal vector of a plethora of viral, bacterial, and protozoan pathogenic microorganisms is showing adaptations to new habitats and ecological conditions. Persistent and potentially increasing populations of this tick species are present in green areas within European cities. Public parks, small forest patches, gardens, and cemeteries are of increasing interest as they represent places where humans, companion, and domestic animals can encounter ticks and be exposed to infected tick bites. The presence of large vertebrates, that serve as tickmaintenance hosts and find conditions to survive and reproduce in the peri-urban environment, reduces the extinction risk of tick populations. Furthermore, majority of tick-maintenance hosts are ecologically classified as generalist species and in many cases serve as reservoirs of a number of emerging zoonotic pathogens, including those transmitted by I. ricinus. The combination of urbanization, climate change, and alterations in land-use patterns along with socio-economic factors (outdoor sports and leisure-time activities, gardening, an increased density of pets, and companion animals near human settlements) act in creating favorable conditions for increasing the exposure of humans to ticks, thus favoring the transmission of tick-borne pathogens in urban and peri-urban areas.

Risk communication campaigns aimed at implementing preventive measures against infectious tick bites in urban and peri-urban habitats therefore deserve particular public health efforts. However, several knowledge gaps and lack of quantitative ecological, epidemiological, and socioecological data limit our ability to provide precise quantitative risk pre-assessment. Therefore, more eco-epidemiological research and surveillance specifically focused on the occurrence of ticks, their infection with pathogenic microorganisms as well as on the presence of tick-maintenance and reservoir vertebrate hosts in urbanized areas is urgently needed. Only a multidisciplinary "One-Health" approach integrating research outputs of specialists from different disciplines (veterinarians, zoologists, ecologists, molecular biologists, epidemiologists, physicians, sociologists, and public health experts, etc.), combined with appropriate outreach and dissemination campaigns, can bring success in making urban and peri-urban areas safer from infection by tick-borne pathogens.

\section{ACKNOWLEDGMENTS}

This study was funded by EU grant FP7-261504 EDENext and is cataloged by the EDENext Steering Committee as EDENext 251 (see text footnote 1). The contents of this publication are the sole responsibility of the authors and do not necessarily reflect the views of the European Commission. Gábor Földvári was supported by the János Bolyai Research Scholarship of the Hungarian Academy of Sciences and NKB and Research Faculty grants from Faculty of Veterinary Science, Szent István University. The work of Cornelia Silaghi, Anna Obiegala and Muriel Vayssier-Taussat was done under the frame of EurNegVec COST Action TD1303. 


\section{REFERENCES}

1. Sonenshine DE, Roe RM. Chapter 1. Overview. 2nd ed. In: Sonenshine DE, Roe RM, editors. Biology of Ticks. (Vol. 1), Oxford: Oxford University Press (2014). p. 3-16.

2. Ginsberg HS, Faulde MK. 10. Ticks. In: Bonnefoy X, Kampen H, Sweeney K, editors. Public Health Significance of Urban Pests. Copenhagen: World Health Organization (2008). p. 303-45.

3. Keesing F, Belden LK, Daszak P, Dobson A, Harvell CD, Holt RD, et al. Impacts of biodiversity on the emergence and transmission of infectious diseases. Nature (2010) 468:647-52. doi:10.1038/nature09575

4. Kilpatrick AM, Randolph SE. Drivers, dynamics, and control of emerging vector-borne zoonotic diseases. Lancet (2012) 380:1946-55. doi:10.1016/ S0140-6736(12)61151-9

5. Karesh WB, Dobson A, Lloyd-Smith JO, Lubroth J, Dixon MA, Bennett M, et al. Ecology of zoonoses: natural and unnatural histories. Lancet (2012) 380:1936-45. doi:10.1016/S0140-6736(12)61678-X

6. Semenza JC, Menne B. Climate change and infectious diseases in Europe. Lancet Infect Dis (2009) 9(6):365-75. doi:10.1016/S1473-3099(09)70104-5

7. Estrada-Pena A, Ostfeld RS, Peterson AT, Poulin R, de la Fuente J. Effects of environmental change on zoonotic disease risk: an ecological primer. Trends Parasitol (2014) 30(4):205-14. doi:10.1016/j.pt.2014.02.003

8. Randolph SE. Tick-borne disease systems emerge from the shadows: the beauty lies in molecular detail, the message in epidemiology. Parasitology (2009) 136:1403-13. doi:10.1017/S0031182009005782

9. Walsh MG. The relevance of forest fragmentation on the incidence of human babesiosis: investigating the landscape epidemiology of an emerging tick-borne disease. Vector Borne Zoonotic Dis (2013) 13(4):250-5. doi:10.1089/vbz.2012. 1198

10. Estrada-Pena A, de la Fuente J. The ecology of ticks and epidemiology of tickborne viral diseases. Antiviral Res (2014) 108:104-28. doi:10.1016/j.antiviral. 2014.05.016

11. Bradley C, Altizer S. Urbanization and the ecology of wildlife diseases. Trends Ecol Evol (2007) 22(2):95-102. doi:10.1016/j.tree.2006.11.001

12. UspenskyY. Tick pests and vectors (Acari: Ixodoidea) in European towns: introduction, persistence and management. Ticks Tick Borne Dis (2014) 5(1):41-7. doi:10.1016/j.ttbdis.2013.07.011

13. United Nations. World Urbanization Prospects. The 2007 Revision. New York, NY: Department of Economic and Social Affairs, Population Division, United Nations (2008). Available from: http://www.un.org/esa/population/ publications/wup2007/2007WUP_Highlights_web.pdf

14. Ellis EC, Ramankutty N. Putting people in the map: anthropogenic biomes of the world. Front Ecol Environ (2008) 6(8):439-47. doi:10.1890/070062

15. McKinney ML. Urbanization as a major cause of biotic homogenization. Biol Conserv (2006) 127:247-60. doi:10.1016/j.biocon.2005.09.005

16. McKinney ML. Effects of urbanization on species richness: a review of plants and animals. Urban Ecosyst (2008) 11:161-76. doi:10.1007/s11252-007-0045-4

17. Faeth SH, Bang C, Saari S. Urban biodiversity: patterns and mechanisms. Ann N Y Acad Sci (2011) 1223:69-81. doi:10.1111/j.1749-6632.2010.05925.x

18. Niemelä J. Urban Ecology, Patterns, Processes, and Applications. New York, NY: Oxford University Press (2011). 392 p.

19. Pfäffle M, Littwin N, Muders SV, Petney TN. The ecology of tick-borne diseases. Int J Parasitol (2013) 43(12-13):1059-77. doi:10.1016/j.ijpara.2013.06.009

20. Deplazes P, Hegglin D, Gloor S, Romig T. Wilderness in the city: the urbanization of Echinococcus multilocularis. Trends Parasitol (2004) 20(2):78-84. doi:10.1016/j.pt.2003.11.011

21. Földvári G, Rigó K, Jablonszky M, Biró N, Majoros G, Molnár V, et al. Ticks and the city: ectoparasites of the Northern white-breasted hedgehog (Erinaceus roumanicus) in an urban park. Ticks Tick Borne Dis (2011) 2:231-4. doi:10.1016/j.ttbdis.2011.09.001

22. Dautel H, Kahl O. In: Robinson WH, Rettich F, Rambo GW, editors. Ticks (Acari: Ixodoidea) and their Medical Importance in the Urban Environment. Prague: Proceedings of the 3rd International Conference on Urban Pests (1999). p. 73-82.

23. Comer JA, Paddock CD, Childs JE. Urban zoonoses Caused by Bartonella, Coxiella, Ehrlichia, and Rickettsia species. Vector Borne Zoonotic Dis (2001) 1(2):91-118. doi:10.1089/153036601316977714

24. Heyman P, Cochez C, Hofhuis A, van der Giessen J, Sprong H, Porter SR, et al. A clear and present danger: tick-borne diseases in Europe. Expert Rev Anti Infect Ther (2010) 8(1):33-50. doi:10.1586/eri.09.118
25. Salman M, Tarrés-Call J. Ticks and Tick-Borne Diseases. Geographical Distribution and Control Strategies in the Euro-Asia region. Wallingford: CABI (2013). $292 \mathrm{p}$.

26. Medlock JM, Hansford KM, Bormane A, Derdakova M, Estrada-Peña A, George $\mathrm{J}-\mathrm{C}$, et al. Driving forces for changes in geographical distribution of Ixodes ricinus ticks in Europe. Parasit Vectors (2013) 6:1. doi:10.1186/1756-3305-6-1

27. Sonenshine DE, Roe RM. Biology of Ticks. 2nd ed. (Vol. 2). Oxford: Oxford University Press (2014). 491 p.

28. Hai VV, Almeras L, Socolovschi C, Raoult D, Parola P, Pagès F. Monitoring human tick-borne disease risk and tick bite exposure in Europe: available tools and promising future methods. Ticks Tick Borne Dis (2014) 5:607-19. doi:10.1016/j.ttbdis.2014.07.022

29. Daniel M, Materna J, Hönig V, Metelka L, Danielová V, Harčarik J, et al. Vertical distribution of the tick Ixodes ricinus and tick-borne pathogens in the northern Moravian mountains correlated with climate warming (Jeseníky Mts., Czech Republic). Cent Eur J Public Health (2009) 17(3):139-45.

30. Jore $S$, Viljugrein $H$, Hofshagen $M$, Brun-Hansen $H$, Kristoffersen $A B$, Nygård $\mathrm{K}$, et al. Multi-source analysis reveals latitudinal and altitudinal shifts in range of Ixodes ricinus at its northern distribution limit. Parasit Vectors (2011) 4:84. doi:10.1186/1756-3305-4-84

31. Jaenson TGT, Jaenson DGE, Eisen L, Petersson E, Lindgren E. Changes in the geographical distribution and abundance of the tick Ixodes ricinus during the past 30 years in Sweden. Parasit Vectors (2012) 5:8. doi:10.1186/1756-3305-5-8

32. Léger E, Vourc'h G, Vial L, Chevillon C, McCoy KD. Changing distributions of ticks: causes and consequences. Exp Appl Acarol (2013) 59(1-2):219-44. doi:10.1007/s10493-012-9615-0

33. Gern L, Rouvinez E, Toutoungi LN, Godfroid E. Transmission cycles of Borrelia burgdorferi sensu lato involving Ixodes ricinus and/or I. hexagonus ticks and the European hedgehog, Erinaceus europaeus, in suburban and urban areas in Switzerland. Folia Parasitol (Praha) (1997) 44(4):309-14.

34. Ogden NH, Cripps P, Davison CC, Owen G, Parry JM, Timms BJ, et al. The Ixodid tick species attaching to domestic dogs and cats in Great Britain and Ireland. Med Vet Entomol (2000) 14:332-8. doi:10.1046/j.1365-2915.2000.00244.x

35. Junttila J, Peltomaa M, Soini H, Marjamäki M, Viljanen MK. Prevalence of Borrelia burgdorferi in Ixodes ricinus ticks in urban recreational areas of Helsinki. J Clin Microbiol (1999) 37:1361-5.

36. Maetzel D, Maier WA, Kampen H. Borrelia burgdorferi infection prevalences in questing Ixodes ricinus ticks (Acari: Ixodidae) in urban and suburban Bonn, western Germany. Parasitol Res (2005) 95:5-12. doi:10.1007/s00436004-1240-3

37. Schorn S, Pfister K, Reulen H, Mahling M, Silaghi C. Occurrence of Babesia spp., Rickettsia spp. and Bartonella spp. in Ixodes ricinus in Bavarian public parks, Germany. Parasit Vectors (2011) 4:135. doi:10.1186/1756-3305-4- 135

38. Wielinga PR, Gaasenbeek C, Fonville M, de Boer A, de Vries A, Dimmers W, et al. Longitudinal analysis of tick densities and Borrelia, Anaplasma, and Ehrlichia infections of Ixodes ricinus ticks in different habitat areas in the Netherlands. Appl Environ Microbiol (2006) 72(12):7594-601. doi:10.1128/ AEM.01851-06

39. Žákovská A, Nejezchlebová H, Bartonková N, Rašovská T, Kučerová H, Norek A, et al. Activity of the tick Ixodes ricinus monitored in a suburban park in Brno, Czech Republic, in association with the evaluation of selected repellents. J Vector Ecol (2013) 38(2):295-300. doi:10.1111/j.1948-7134.2013.12043.x

40. Pangrácová L, Derdáková M, Pekárik L, Hvišcová I, Víchová B, Stanko M, et al. Ixodes ricinus abundance and its infection with the tick-borne pathogens in urban and suburban areas of Eastern Slovakia. Parasit Vectors (2013) 6(1):238. doi:10.1186/1756-3305-6-238

41. Welc-Faleciak R, Kowalec M, Karbowiak G, Bajer A, Behnke JM, Sinski E. Rickettsiaceae and Anaplasmataceae infections in Ixodes ricinus ticks from urban and natural forested areas of Poland. Parasit Vectors (2014) 7(1):121 doi:10.1186/1756-3305-7-121

42. Bowmann A, Nuttall P. Ticks. Biology, Disease and Control. New York, NY: Cambridge University Press (2008). 506 p.

43. Balashov YS. Ixodid Ticks, Parasites and Vectors of Infections. St. Petersburg: Nauka (1998).

44. Gray J, Kahl O, Lane RS, Stanek G. Lyme Borreliosis Biology, Epidemiology and Control. Wallingford: CABI (2002). 480 p.

45. Pichon B, Estrada-Pena A, Kahl O, Mannelli A, Gray S. Detection of animal reservoirs of tick-borne zoonoses in Europe. Int J Med Microbiol (2006) 296:129-30. doi:10.1016/j.ijmm.2006.01.016 
46. Richter D, Schlee DB, Matuschka F-R. Reservoir competence of various rodents for the lyme disease spirochete Borrelia spielmanii. Appl Environ Microbiol (2011) 77:3565-70. doi:10.1128/AEM.00022-11

47. Kozuch O, Gresikova M, Nosek J, Lichard M, Sekeyova M. The role of small rodents and hedgehogs in a natural focus of tick-borne encephalitis. Bull World Health Organ (1967) 36:61-6.

48. Burri C, Schumann O, Schumann C, Gern L. Are Apodemus spp. mice and Myodes glareolus reservoirs for Borrelia miyamotoi, Candidatus Neoehrlichia mikurensis, Rickettsia helvetica, R. monacensis and Anaplasma phagocytophilum? Ticks Tick Borne Dis (2014) 5:245-51. doi:10.1016/j.ttbdis.2013.11. 007

49. Yabsley MJ, Shock BC. Natural history of zoonotic Babesia: role of wildlife reservoirs. Int J Parasitol (2013) 2:18-31. doi:10.1016/j.ijppaw.2012.11.003

50. Stuen S, Granquist EG, Silaghi C. Anaplasma phagocytophilum - a widespread multi-host pathogen with highly adaptive strategies. Front Cell Infect Microbiol (2013) 3:31. doi:10.3389/fcimb.2013.00031

51. Hubálek Z, Rudolf I. Tick-borne viruses in Europe. Parasitol Res (2012) 111:9-36. doi:10.1007/s00436-012-2910-1

52. Silaghi C, Woll D, Mahling M, Pfister K, Pfeffer M. Candidatus Neoehrlichia mikurensis in rodents in an area with sympatric existence of the hard ticks Ixodes ricinus and Dermacentor reticulatus, Germany. Parasit Vectors (2012) 5:285. doi:10.1186/1756-3305-5-285

53. Sebek Z, Rosický B, Sixl W. The occurrence of babesiasis is affecting small terrestrial mammals and the importance of this zoonosis in Europe. Folia Parasitol (Praha) (1977) 24(3):221-8.

54. Piksa K, Górz A, Nowak-Chmura M, Siuda K. The patterns of seasonal activity of Ixodes vespertilionis (Acari: Ixodidae) on Rhinolophus hipposideros in nursery colonies. Ticks Tick Borne Dis (2014) 5:69-74. doi:10.1016/j.ttbdis.2013.08.006

55. Silaghi C, Woll D, Hamel D, Pfister K, Mahling M, Pfeffer M. Babesia sp and Anaplasma phagocytophilum in questing ticks, ticks parasitizing rodents and the parasitized rodents - analyzing the host-pathogen-vector interface in a metropolitan area. Parasit Vectors (2012) 5:191. doi:10.1186/1756-3305-5-191

56. Krücken J, Schreiber C, Maaz D, Kohn M, Demeler J, Beck S, et al. A novel high-resolution melt PCR assay discriminates Anaplasma phagocytophilum and “Candidatus Neoehrlichia mikurensis". J Clin Microbiol (2013) 51:1958-61. doi:10.1128/JCM.00284-13

57. Matuschka FR, Endepols S, Richter D, Spielman A. Competence of urban rats as reservoir hosts for Lyme disease spirochetes. J Med Entomol (1997) 34:489-93.

58. Földvári G, Farkas R, Lakos A. Borrelia spielmanii Erythema Migrans, Hungary. Emerg Infect Dis (2005) 11:2004-5. doi:10.3201/eid1111.050542

59. Craine NG, Nuttall PA, Marriott AC, Randolph SE. Role of grey squirrels and pheasants in the transmission of Borrelia burgdorferi sensu lato, the Lyme disease spirochaete, in the U.K. Folia Parasitol (Praha) (1997) 44(2):155-60.

60. Humair PF, Gern L. Relationship between Borrelia burgdorferi sensu lato species, red squirrels (Sciurus vulgaris) and Ixodes ricinus in enzootic areas in Switzerland. Acta Trop (1998) 69:213-27. doi:10.1016/S0001-706X(97) 00126-5

61. Pisanu B, Chapuis J-L, Dozières A, Basset F, Poux V, Vourc'h G. High prevalence of Borrelia burgdorferi s.l. in the European red squirrel Sciurus vulgaris in France. Ticks Tick Borne Dis (2014) 5:1-6. doi:10.1016/j.ttbdis.2013.07.007

62. Marsot M, Sigaud M, Chapuis JL, Ferquel E, Cornet M, Vourc'h G. Introduced Siberian chipmunks (Tamias sibiricus barberi) harbor more-diverse Borrelia burgdorferi sensu lato genospecies than native bank voles (Myodes glareolus). Appl Environ Microbiol (2011) 77:5716-21. doi:10.1128/AEM.01846-10

63. Tallekint L, Jaenson T. Maintenance by hares of European Borrelia burgdorferi in ecosystems without rodents. J Med Entomol (1993) 30:273-6.

64. Skuballa J, Petney T, Pfäffle M, Oehme R, Hartelt K, Fingerle V, et al. Occurrence of different Borrelia burgdorferi sensu lato genospecies including B. afzelii, B. bavariensis, and B. spielmanii in hedgehogs (Erinaceus sp) in Europe. Ticks Tick Borne Dis (2011) 3(1):8-13. doi:10.1016/j.ttbdis.2011.09.008

65. Gern L, Rouvinez E, Toutoungi LEG. Transmission cycles of Borrelia burgdorferi sensu lato involving Ixodes ricinus and/or I. hexagonus ticks and the European hedgehog, Erinaceus europaeus, in suburban and urban areas in Switzerland. Folia Parasitol (Praha) (1997) 44:309-14.

66. Gray JS, Kahl O, Janetzki-Mittman C, Stein J, Guy E. Acquisition of Borrelia burgdorferi by Ixodes ricinus ticks fed on the European hedgehog, Erinaceus europaeus L. Exp Appl Acarol (1994) 18:485-91. doi:10.1007/BF00051470

67. Silaghi C, Skuballa J, Thiel C, Pfister K, Petney T, Pfäffle M, et al. The European hedgehog (Erinaceus europaeus) - a suitable reservoir for variants of Anaplasma phagocytophilum? Ticks Tick Borne Dis (2012) 3(1):49-54. doi:10.1016/j.ttbdis.2011.11.005

68. Skuballa JD, Petney T, Pfaffle M, Taraschewski H. Molecular detection of Anaplasma phagocytophilum in the European hedgehog (Erinaceus europaeus) and its ticks. Vector Borne Zoonotic Dis (2010) 10:1055-7. doi:10.1089/vbz. 2009.0150

69. Földvári G, Jahfari S, Rigó K, Jablonszky M, Szekeres S, Majoros G, et al. Candidatus Neoehrlichia mikurensis and Anaplasma phagocytophilum in urban hedgehogs. Emerg Infect Dis (2014) 20:496-8. doi:10.3201/eid2003.130935

70. Overzier E, Pfister K, Herb I, Mahling M, Böck G, Silaghi C. Detection of tickborne pathogens in roe deer (Capreolus capreolus), in questing ticks (Ixodes ricinus), and in ticks infesting roe deer in southern Germany. Ticks Tick Borne Dis (2013) 4:320-8. doi:10.1016/j.ttbdis.2013.01.004

71. Robinson MT, Shaw SE, Morgan ER. Anaplasma phagocytophilum infection in a multi-species deer community in the New Forest, England. Eur J Wildl Res (2009) 55:439-42. doi:10.1007/s10344-009-0261-8

72. Härtwig V, von Loewenich FD, Schulze C, Straubinger RK, Daugschies A, Dyachenko V. Detection of Anaplasma phagocytophilum in red foxes (Vulpes vulpes) and raccoon dogs (Nyctereutes procyonoides) from Brandenburg, Germany. Ticks Tick Borne Dis (2014) 5(3):277-80. doi:10.1016/j.ttbdis.2013.11. 001

73. Gern L, Sell K. Isolation of Borrelia burgdorferi sensu lato from the skin of the European badger (Meles meles) in Switzerland. Vector Borne Zoonotic Dis (2009) 9:207-8. doi:10.1089/vbz.2008.0050

74. Hubert P, Julliard R, Biagianti S, Poulle M. Landscape and urban planning ecological factors driving the higher hedgehog (Erinaceus europaeus) density in an urban area compared to the adjacent rural area. Landsc Urban Plan (2011) 103:34-43. doi:10.1016/j.landurbplan.2011.05.010

75. Macdonald DW, Newdick MT. The distribution and ecology of foxes, Vulpes vulpes (L.) in urban areas. In: Lee R, Bornkamm JA, Seaward MRD, editors. Urban Ecology. Oxford: Blackwell Scientific Publications (1982). p. 123-35.

76. Bateman PW, Fleming PA. Big city life: carnivores in urban environments. J Zool (2012) 287(1):1-23. doi:10.1111/j.1469-7998.2011.00887.x

77. Mihalca AD, Sándor AD. The role of rodents in the ecology of Ixodes ricinus and associated pathogens in Central and Eastern Europe. Front Cell Infect Microbiol (2013) 3:56. doi:10.3389/fcimb.2013.00056

78. Ostfeld RS, Levi T, Jolles AE, Martin LB, Hosseini PR, Keesing F. Life history and demographic drivers of reservoir competence for three tick-borne zoonotic pathogens. PLoS One (2014) 9(9):e107387. doi:10.1371/journal.pone. 0107387

79. Gage KL, Kosoy MY. 13. Non-commensal rodents and lagomorphs. In: Bonnefoy X, Kampen H, Sweeney K, editors. Public Health Significance of Urban Pests. Denmark: World Health Organization (2008). p. 421-76.

80. Olsson GE, Leirs H, Henttonen H. Hantaviruses and their hosts in Europe: reservoirs here and there, but not everywhere? Vector Borne Zoonotic Dis (2010) 10(6):549-61. doi:10.1089/vbz.2009.0138

81. Dziemian S, Michalik J, Pi Łacinska B, Bialik S, Sikora B, Zwolak R. Infestation of urban populations of the Northern white-breasted hedgehog, Erinaceus roumanicus, by Ixodes spp. ticks in Poland. Med Vet Entomol (2014) 28(4):4659. doi:10.1111/mve.12065

82. Benassi G, Bertolino S. Distribution and activity of the introduced Tamias sibiricus (Laxmann, 1769) in an urban park in Rome, Italy. Mammalia (2011) 75:87-90. doi:10.1515/mamm.2010.066

83. Bertolino S, Currado I, Mazzoglio PJ, Amori G. Native and alien squirrels in Italy. Hystrix (n.s.) (2000) 11(2):65-74.

84. Long JL. Introduced Mammals of the World: Their History, Distribution, and Influence. Collingwood, VIC: CABI and CSIRO Publishing (2003). 612 p.

85. Vourc'h G, Marmet J, Chassagne M, Bord S, Chapuis J-L. Borrelia burgdorferi sensu lato in Siberian chipmunks (Tamias sibiricus) introduced in suburban forests in France. Vector Borne Zoonotic Dis (2007) 7(4):637-41. doi:10.1089/vbz.2007.0111

86. Pisanu B, Marsot M, Marmet J, Chapuis JL, Reale D, Vourc'h G. Introduced Siberian chipmunks are more heavily infested by ixodid ticks than are native bank voles in a suburban forest in France. Int J Parasitol (2010) 40:1277-83. doi:10.1016/j.ijpara.2010.03.012

87. Frank R, Kuhn T, Mehlhorn H, Rueckert S, Pham D, Klimpel S. Parasites of wild rabbits (Oryctolagus cuniculus) from an urban area in Germany, in relation to worldwide results. Parasitol Res (2013) 112:4255-66. doi:10.1007/s00436-013-3617-7 
88. Siuda K, Stanko M, Piksa K, Górz A. Ticks (Acari: Ixodida) parasitizing bats in Poland and Slovakia. Wiad Parazytol (2009) 55(1):39-45.

89. Carpi G, Cagnacci F, Neteler M, Rizzoli A. Tick infestation on roe deer in relation to geographic and remotely sensed climatic variables in a tickborne encephalitis endemic area. Epidemiol Infect (2008) 136(10):1416-24. doi:10.1017/S0950268807000039

90. Meyer-Kayser E, Hoffmann L, Silaghi C, Pfister K, Mahling M, Passos LM. Dynamics of tick infestations in foxes in Thuringia, Germany. Ticks Tick Borne Dis (2012) 3(4):232-9. doi:10.1016/j.ttbdis.2012.05.004

91. Cagnacci F, Bolzoni L, Rosà R, Carpi G, Hauffe HC, Valent M, et al. Effect of deer density on tick infestation of rodents and TBE hazard. Part I: empirical assessment. Int J Parasitol (2012) 42(4):365-72. doi:10.1016/j.ijpara.2012.02.012

92. Gaillard JM, Hewison AJ, Klein F, Plard F, Douhard M, Davison R, et al. How does climate change influence demographic processes of widespread species? Lessons from the comparative analysis of contrasted populations of roe deer. Ecol Lett (2013) 16(Suppl 1):48-57. doi:10.1111/ele.12059

93. Jensen PM, Hansen H, Frandsen F. Spatial risk assessment for Lyme borreliosis in Denmark. Scand J Infect Dis (2000) 32:545-50. doi:10.1080/ 003655400458857

94. Rizzoli AP, Hauffe HC, Tagliapietra V, Neteler M, Rosà R. Forest structure and roe deer abundance predict tick-borne encephalitis risk in Italy. PLoS One (2009) 4:e4336. doi:10.1371/journal.pone.0004336

95. Qviller L, Risnes-Olsen N, Bærum KM, Meisingset EL, Loe LE, Ytrehus B, et al. Landscape level variation in tick abundance relative to seasonal migration in red deer. PLoS One (2013) 8(8):e71299. doi:10.1371/journal.pone.0071299

96. Vor T, Kiffner C, Hagedorn P, Niedrig M, Rühe F. Tick burden on European roe deer (Capreolus capreolus). Exp Appl Acarol (2010) 51(4):405-17. doi:10.1007/s10493-010-9337-0

97. Pacilly FC, Benning ME, Jacobs F, Leidekker J, Sprong H, Van Wieren SE, et al. Blood feeding on large grazers affects the transmission of Borrelia burgdorferi sensu lato by Ixodes ricinus. Ticks Tick Borne Dis (2014) 5(6):810-7. doi:10.1016/j.ttbdis.2014.06.004

98. Schley L, Roper TJ. Diet of wild boar Sus scrofa in Western Europe, with particular reference to consumption of agricultural crops. Mamm Rev (2003) 33:43-56. doi:10.1046/j.1365-2907.2003.00010.x

99. Jahfari S, Coipan EC, Fonville M, van Leeuwen A, Hengeveld PD, Heylen D, et al. Circulation of four Anaplasma phagocytophilum ecotypes in Europe. Parasit Vectors (2014) 7:365. doi:10.1186/1756-3305-7-365

100. Deplazes P. Ecology and epidemiology of Echinococcus multilocularis in Europe. Parassitologia (2006) 48(1-2):37-9.

101. Scott DM, Berg MJ, Tolhurst BA, Chauvenet AL, Smith GC, Neaves K, et al. Changes in the distribution of red foxes (Vulpes vulpes) in urban areas in Great Britain: findings and limitations of a media-driven nationwide survey. PLoS One (2014) 9(6):e99059. doi:10.1371/journal.pone.0099059

102. Dumitrache MO, D’Amico G, Matei IA. Ixodid ticks in red foxes (Vulpes vulpes) from Romania. Parasit Vectors (2014) 7(Suppl 1):1. doi:10.7589/2013-07-167

103. Földvári G, Farkas R. Ixodid tick species attaching to dogs in Hungary. Vet Parasitol (2005) 129(1-2):125-31. doi:10.1016/j.vetpar.2004.11.032

104. Földvári G, Márialigeti M, Solymosi N, Lukács Z, Majoros G, Kósa JP, et al. Hard ticks infesting dogs in Hungary and their infection with Babesia and Borrelia species. Parasitol Res (2007) 101(Suppl 1):25-34. doi:10.1007/s00436007-0608-6

105. Hamel D, Silaghi C, Lescai D, Pfister K. Epidemiological aspects on vectorborne infections in stray and pet dogs from Romania and Hungary with focus on Babesia spp. Parasitol Res (2012) 110(4):1537-45. doi:10.1007/s00436-0112659-y

106. Trotta M, Nicetto M, Fogliazza A, Montarsi F, Caldin M, Furlanello T, et al. Detection of Leishmania infantum, Babesia canis, and rickettsiae in ticks removed from dogs living in Italy. Ticks Tick Borne Dis (2012) 3(5-6):294-7. doi:10.1016/j.ttbdis.2012.10.031

107. Available from: http://www.occupyforanimals.net/europes-homeless-animals. html

108. Hubálek Z. 8. Birds. In: Bonnefoy X, Kampen H, Sweeney K, editors. Public Health Significance of Urban Pests. Denmark: World Health Organization (2008). p. 239-87.

109. Hamer SA, Goldberg TL, Kitron UD, Brawn JD, Anderson TK, Loss SR, et al. Wild birds and urban ecology of ticks and tick-borne pathogens, Chicago, Illinois, USA, 2005-2010. Emerg Infect Dis (2012) 18(10):1589-95. doi:10.3201/eid1810.120511
110. Norte AC, de Carvalho IL, Ramos JA, Gonçalves M, Gern L, Núncio MS. Diversity and seasonal patterns of ticks parasitizing wild birds in western Portugal. Exp Appl Acarol (2012) 58(3):327-39. doi:10.1007/s10493-012-9583-4

111. Taragel'ová V, Koči J, Hanincová K, Olekšák M, Labuda M. Songbirds as hosts for ticks (Acari, Ixodidae) in Slovakia. Biologia (2005) 60(5):529-37.

112. Taragel’ová V, Koči J, Hanincová K, Kurtenbach K, Derdáková M, Ogden NH, et al. Blackbirds and song thrushes constitute a key reservoir of Borrelia garinii, the causative agent of Borreliosis in central Europe. Appl Environ Microbiol (2008) 74:1289-93. doi:10.1128/AEM.01060-07

113. Hildebrandt A, Franke J, Meier F, Sachse S, Dorn W, Straube E. The potential role of migratory birds in transmission cycles of Babesia spp., Anaplasma phagocytophilum, and Rickettsia spp. Ticks Tick Borne Dis (2010) 1:105-7. doi:10.1016/j.ttbdis.2009.12.003

114. Hasle G. Transport of ixodid ticks and tick-borne pathogens by migratory birds. Front Cell Infect Microbiol (2013) 3:48. doi:10.3389/fcimb.2013.00048

115. Hurlbert AH, Liang Z. Spatiotemporal variation in avian migration phenology: citizen science reveals effects of climate change. PLoS One (2012) 7:e31662. doi:10.1371/journal.pone.0031662

116. Van Vliet J, Musters CJM, Ter Keurs WJ. Changes in migration behaviour of Blackbirds Turdus merula from the Netherlands. Bird Study (2009) 56:276-81. doi:10.1080/00063650902792148

117. Sándor AD, Mărcutan DI, D’Amico G, Gherman CM, Dumitrache MO, Mihalca AD. Do the ticks of birds at an important migratory hotspot reflect the seasonal dynamics of Ixodes ricinus at the migration initiation site? A case study in the Danube Delta. PLoS One (2014) 9:e89378. doi:10.1371/journal.pone.0089378

118. Baráková I, Derdáková M, Carpi G, Rosso F, Collini M, Tagliapietra V, et al. Genetic and ecologic variability among Anaplasma phagocytophilum strains, northern Italy. Emerg Infect Dis (2014) 20(6):1082-5. doi:10.3201/eid2006. 131023

119. Capligina V, Salmane I, Keišs O, Vilks K, Japina K, Baumanis V, et al. Prevalence of tick-borne pathogens in ticks collected from migratory birds in Latvia. Ticks Tick Borne Dis (2014) 5:75-81. doi:10.1016/j.ttbdis.2013.08.007

120. Hornok S, Kováts D, Csörgő T, Meli ML, Gönczi E, Hadnagy Z, et al. Birds as potential reservoirs of tick-borne pathogens: first evidence of bacteraemia with Rickettsia helvetica. Parasit Vectors (2014) 7:128. doi:10.1186/ 1756-3305-7- 128

121. Bauwens D, Strijbosch H, Stumpel A. The lizards Lacerta agilis and L. vivipara as hosts to larvae and nymphs of the tick Ixodes ricinus. Holarct Ecol (1983) 6:32-40.

122. Richter D, Matuschka F. Perpetuation of the Lyme disease spirochete Borrelia lusitaniae by lizards. Appl Environ Microbiol (2006) 72:4627-32. doi:10.1128/ AEM.00285-06

123. Földvári G, Rigó K, Majláthová V, Majláth I, Farkas R, Petko B. Detection of Borrelia burgdorferi sensu lato in lizards and their ticks from Hungary. Vector Borne Zoonotic Dis (2009) 9:331-6. doi:10.1089/vbz.2009.0021

124. Tijsse-Klasen E, Fonville M, Reimerink JHJ, Spitzen-van der A, Sprong H. Role of sand lizards in the ecology of Lyme and other tick-borne diseases in the Netherlands. Parasit Vectors (2010) 3:42. doi:10.1186/1756-3305-3-42

125. Majláthová V, Majláth I, Derdáková M, Víchová B, Petko B. Borrelia lusitaniae and green lizards (Lacerta viridis), Karst Region, Slovakia. Emerg Infect Dis (2006) 12:1895-901. doi:10.3201/eid1212.060784

126. Majláthová V, Majláth I, Hromada M, Tryjanowski P, Bona M, Antczak M, et al. The role of the sand lizard (Lacerta agilis) in the transmission cycle of Borrelia burgdorferi sensu lato. Int J Med Microbiol (2008) 298:161-7. doi:10.1016/j.ijmm.2008.03.005

127. Gritsun TS, Lashkevich VA, Gould EA. Tick-borne encephalitis. Antiviral Res (2003) 57(1-2):129-46. doi:10.1016/S0166-3542(02)00206-1

128. Rizzoli A, Hauffe HC, Carpi G, Vourc'h GI, Neteler M, Rosà R. Lyme borreliosis in Europe. Euro Surveill (2011) 16(27):19906.

129. Grankvist A, Andersson P-O, Mattsson M, Sender M, Vaht K, Höper L, et al. Infections with the tick-borne bacterium "Candidatus Neoehrlichia mikurensis" mimic non-infectious conditions in patients with B cell malignancies or autoimmune diseases. Clin Infect Dis (2014) 58(12):1716-22. doi:10.1093/cid/ciul89

130. Li H, Jiang JF, Liu W, Zheng YC, Huo QB, Tang K, et al. Human infection with Candidatus Neoehrlichia mikurensis, China. Emerg Infect Dis (2012) 18:1636-8. doi:10.3201/eid1810.120594

131. Parola P, Paddock CD, Socolovschi C, Labruna MB, Mediannikov O, Kernif $\mathrm{T}$, et al. Update on tick-borne rickettsioses around the world: 
a Geographic approach. Clin Microbiol Rev (2013) 26(4):657-702. doi:10.1128/ CMR.00032-13

132. Gray J, Zintl A, Hildebrandt A, Hunfeld K-P, Weiss L. Zoonotic babesiosis: overview of the disease and novel aspects of pathogen identity. Ticks Tick Borne Dis (2010) 1:3-10. doi:10.1016/j.ttbdis.2009.11.003

133. Socolovschi C, Mediannikov O, Raoult D, Parola P. Update on tick-borne bacterial diseases in Europe. Parasite (2009) 16:259-73. doi:10.1051/parasite/ 2009164259

134. WHO. The Vector-Borne Human Infections of Europe: Their Distribution and Burden on Public Health. Copenhagen: WHO Regional Office for Europe (WHO/EURO) (2004). 144 p. Avaliable from: http://www.euro.who.int/_ data/assets/pdf_file/0008/98765/e82481.pdf

135. Kunze U. ISW-TBE. Tick-borne encephalitis - a notifiable disease: report of the 15th annual meeting of the International Scientific Working Group on tick-borne encephalitis (ISW-TBE). Ticks Tick Borne Dis (2013) 4:363-5.

136. Heinz FX, Stiasny K, Holzmann H, Grgic-Vitek M, Kriz B, Essl A, et al. Vaccination and tick-borne encephalitis, central Europe. Emerg Infect Dis (2013) 19:69-76. doi:10.3201/eid1901.120458

137. Dobler G, Gniel D, Petermann R, Pfeffer M. Epidemiology and distribution of tick-borne encephalitis. Wien Med Wochenschr (2012) 162:230-8. doi:10.1007/s10354-012-0100-5

138. Amicizia D, Domnich A, Panatto D, Lai PL, Cristina ML, Avio U, et al. Epidemiology of tick-borne encephalitis (TBE) in Europe and its prevention by available vaccines. Hum Vaccin Immunother (2013) 9(5):1163-71. doi:10.4161/hv.23802

139. Danielová V, Daniel M, Schwarzová L, Materna J, Rudenko N, Golovchenko $\mathrm{M}$, et al. Integration of a tick-borne encephalitis virus and Borrelia burgdorferi sensu lato into mountain ecosystems, following a shift in the altitudinal limit of distribution of their vector, Ixodes ricinus (Krkonose mountains, Czech Republic). Vector Borne Zoonotic Dis (2010) 10(3):223-30. doi:10.1089/vbz.2009.0020

140. Randolph SE. The shifting landscape of tick-borne zoonoses: tick-borne encephalitis and Lyme borreliosis in Europe. Philos Trans R Soc Lon B Biol Sci (2001) 356:1045-56. doi:10.1098/rstb.2001.0893

141. Randolph SE. Evidence that climate change has caused 'emergence' of tickborne diseases in Europe? Int J Med Microbiol (2004) 293(Suppl 37):5-15. doi:10.1016/S1433-1128(04)80004-4

142. Randolph SE. Tick-borne encephalitis incidence in Central and Eastern Europe: consequences of political transition. Microbes Infect (2008) 10:209-16. doi:10.1016/j.micinf.2007.12.005

143. Semenza JC, Suk JE, Estevez V, Ebi KL, Lindgren E. Mapping climate change vulnerabilities to infectious diseases in Europe. Environ Health Perspect (2012) 120:385-92. doi:10.1289/ehp.1103805

144. Sumilo D, Bormane A, Asokliene L, Vasilenko V, Golovljova I, Avsic-Zupanc $\mathrm{T}$, et al. Socio-economic factors in the differential upsurge of tick-borne encephalitis in Central and Eastern Europe. Rev Med Virol (2008) 18:81-95. doi: $10.1002 / \mathrm{rmv} .566$

145. Holzmann H, Aberle SW, Stiasny K, Werner P, Mischak A, Zainer B, et al. Tickborne encephalitis from eating goat cheese in a mountain region of Austria. Emerg Infect Dis (2009) 15:1671-3. doi:10.3201/eid1510.090743

146. Balogh Z, Ferenczi E, Szeles K, Stefanoff P, Gut W, Szomor KN, et al. Tick-borne encephalitis outbreak in Hungary due to consumption of raw goat milk. J Virol Methods (2010) 163:481-5. doi:10.1016/j.jviromet.2009.10.003

147. Hudopisk N, Korva M, Janet E, Simetinger M, Grgic-Vitek M, Gubenšek J, et al. Tick-borne encephalitis associated with consumption of raw goat milk, Slovenia, 2012. Emerg Infect Dis (2013) 19:806-8. doi:10.3201/eid1905. 121442

148. Zeman P, Benes C. Spatial distribution of a population at risk: an important factor for understanding the recent rise in tick-borne diseases (Lyme borreliosis and tick-borne encephalitis in the Czech Republic). Ticks Tick Borne Dis (2013) 4:522-30. doi:10.1016/j.ttbdis.2013.07.003

149. Stefanoff P, Zielicka-Hardy A, Hlebowicz M, Konior R, Lipowski D, Szenborn L, et al. New endemic foci of tick-borne encephalitis (TBE) identified in districts where testing for TBE was not available before 2009 in Poland. Parasit Vectors (2013) 6:180. doi:10.1186/1756-3305-6-180

150. Korenberg E, Cerný V, Daniel M. Occurrence of ixodid ticks - the main vectors of tick-borne encephalitis virus in urbanized territory. Folia Parasitol (Praha) (1984) 31:365-70.

151. Nuttall PA, Labuda M. Dynamics of infection in tick vectors and at the tickhost interface. Adv Virus Res (2003) 60:233-72. doi:10.1016/S0065-3527(03) 60007-2
152. Labuda M, Kozuch O, Zuffová E, Elecková E, Hails RS, Nuttall PA. Tickborne encephalitis virus transmission between ticks cofeeding on specific immune natural rodent hosts. Virology (1997) 235:138-43. doi:10.1006/viro. 1997.8622

153. Süss J. Tick-borne encephalitis 2010: epidemiology, risk areas, and virus strains in Europe and Asia-an overview. Ticks Tick Borne Dis (2011) 2:2-15. doi:10.1016/j.ttbdis.2010.10.007

154. Tonteri E, Jääskeläinen $\mathrm{AE}$, Tikkakoski $\mathrm{T}$, Voutilainen L, Niemimaa J, Henttonen $\mathrm{H}$, et al. Tick-borne encephalitis virus in wild rodents in winter, Finland, 2008-2009. Emerg Infect Dis (2011) 17:72-5. doi:10.3201/eid1701. 100051

155. Achazi K, Růžek D, Donoso-Mantke O, Schlegel M, Ali HS, Wenk M, et al. Rodents as sentinels for the prevalence of tick-borne encephalitis virus. Vector Borne Zoonotic Dis (2011) 11(6):641-7. doi:10.1089/vbz.2010.0236

156. Labuda M, Nuttall PA, Kozuch O, Elecková E, Williams T, Zuffová E, et al. Non-viraemic transmission of tick-borne encephalitis virus: a mechanism for arbovirus survival in nature. Experientia (1993) 49:802-5. doi:10.1007/ BF01923553

157. Randolph SE, Miklisová D, Lysy J, Rogers DJ, Labuda M. Incidence from coincidence: patterns of tick infestations on rodents facilitate transmission of tick-borne encephalitis virus. Parasitology (1999) 118(2):177-86. doi:10.1017/ S0031182098003643

158. Waldenström J, Lundkvist $\AA$, Falk KI, Garpmo U, Bergström S, Lindegren G, et al. Migrating birds and tickborne encephalitis virus. Emerg Infect Dis (2007) 13(8):1215-8. doi:10.3201/eid1308.061416

159. Lommano E, Dvořák C, Vallotton L, Jenni L, Gern L. Tick-borne pathogens in ticks collected from breeding and migratory birds in Switzerland. Ticks Tick Borne Dis (2014) 5(6):871-82. doi:10.1016/j.ttbdis.2014.07.001

160. Kiffner C, Zucchini W, Schomaker P, Vor T, Hagedorn P, Niedrig M, et al. Determinants of tick-borne encephalitis in counties of southern Germany, 2001-2008. Int J Health Geogr (2010) 9:42. doi:10.1186/1476-072X-9-42

161. Palo RT. Tick-borne encephalitis transmission risk: its dependence on host population dynamics and climate effects. Vector Borne Zoonotic Dis (2014) 14(5):346-52. doi:10.1089/vbz.2013.1386

162. Jemeršića L, Deždek D, Brnić D, Prpić J, Janicki Z, Keros T, et al. Detection and genetic characterization of tick-borne encephalitis virus (TBEV) derived from ticks removed from red foxes (Vulpes vulpes) and isolated from spleen samples of red deer (Cervus elaphus) in Croatia. Ticks Tick Borne Dis (2014) 5:7-13. doi:10.1016/j.ttbdis.2012.11.016

163. Bolzoni L, Rosà R, Cagnacci F, Rizzoli A. Effect of deer density on tick infestation of rodents and TBE hazard. Part II: population and infection models. Int J Parasitol (2012) 42:373-81. doi:10.1016/j.ijpara.2012.02.006

164. Klaus C, Beer M, Saier R, Schau U, Moog U, Hoffmann B, et al. Goats and sheep as sentinels for tick-borne encephalitis (TBE) virus - epidemiological studies in areas endemic and non-endemic for TBE virus in Germany. Ticks Tick Borne Dis (2012) 3(1):27-37. doi:10.1016/j.ttbdis.2011.09.011

165. Pfeffer M, Dobler G. Tick-borne encephalitis virus in dogs - is this an issue? Parasit Vectors (2011) 4:59. doi:10.1186/1756-3305-4-59

166. Rizzoli A, Neteler M, Rosà R, Versini W, Cristofolini A, Bregoli M, et al. Early detection of tick-borne encephalitis virus spatial distribution and activity in the province of Trento, northern Italy. Geospat Health (2007) 1(2):169-76.

167. Linquist L, Vapalathi O. Tick-borne encephalitis. Lancet (2008) 371:1861-71. doi:10.1016/S0140-6736(08)60800-4

168. Donoso Mantke O, Escadafal C, Niedrig M, Pfeffer M, on behalf of the Working group for Tick-borne encephalitis virus. Tick-borne encephalitis in Europe, 2007 to 2009. Euro Surveill (2011) 16(39):19976.

169. Stefanoff P, Pfeffer M, Hellenbrand W, Rogalska J, Rühe F, Makówka A, et al. Virus detection in questing ticks is not a sensitive indicator for risk assessment of tick-borne encephalitis in humans. Zoonoses Public Health (2013) 60:215-26. doi:10.1111/j.1863-2378.2012.01517.x

170. Danielová V, Holubová J, Daniel M. Tick-borne encephalitis virus prevalence in Ixodes ricinus ticks collected in high risk habitats of the southBohemian region of the Czech Republic. Exp Appl Acarol (2002) 26:145-51. doi:10.1023/A:1020966605960

171. Carpi G, Bertolotti L, Rosati S, Rizzoli A. Prevalence and genetic variability of tick-borne encephalitis virus in host-seeking Ixodes ricinus in northern Italy. J Gen Virol (2009) 90:2877-83. doi:10.1099/vir.0.013367-0

172. Lommano E, Burri C, Maeder G, Guerne M, Bastic V, Patalas E, et al. Prevalence and genotyping of tick-borne encephalitis virus in questing Ixodes ricinus ticks 
in a new endemic area in western Switzerland. J Med Entomol (2012) 49:156-64. doi:10.1603/ME11044

173. Casati S, Gern L, Piffaretti J-C. Diversity of the population of tick-borne encephalitis virus infecting Ixodes ricinus ticks in an endemic area of central Switzerland. J Gen Virol (2006) 87:2235-41. doi:10.1099/vir.0.81783-0

174. Drelich A, Andreassen Å, Vainio K, Kruszynski P, Wasik TJ. Prevalence of tickborne encephalitis virus in a highly urbanizedand low risk area in Southern Poland. Ticks Tick Borne Dis (2014) 5(6):663-7. doi:10.1016/j.ttbdis.2014.04. 020

175. Biernat B, Karbowiak G, Werszko J, Stanczak J. Prevalence of tick-borne encephalitis virus (TBEV) RNA in Dermacentor reticulatus ticks from natural and urban environment, Poland. Exp Appl Acarol (2014) 64(4):543-51. doi:10.1007/s10493-014-9836-5

176. Radolf JD, Caimano MJ, Stevenson B, Hu LDT. Of ticks, mice and men: understanding the dual-host lifestyle of Lyme disease spirochaetes. Nat Rev Microbiol (2012) 10:87-99. doi:10.1038/nrmicro2714

177. Durden LA, Beati L. Chapter 2. Modern tick systematics. In: Sonenshine DE, Roe RM, editors. Biology of Ticks. (Vol. 1), Oxford: Oxford University Press (2014).p. 17-58.

178. Hubálek Z. Epidemiology of Lyme Borreliosis. Curr Probl Dermatol (2009) 37:31-50. doi:10.1159/000213069

179. Stanek G, Reiter M. The expanding Lyme Borrelia complex - clinical significance of genomic species? Clin Microbiol Infect (2011) 17(4):487-93. doi:10.1111/j.1469-0691.2011.03492.x

180. Franke J, Hildebrandt A, Dorn W. Exploring in our knowledge on Lyme borreliosis spirochaetes - updates on complex heterogeneity, ecology and pathogenicity. Ticks Tick-Borne Dis (2013) 4(1-2):11-25. doi:10.1016/j.ttbdis.2012. 06.007

181. Fitzner J, Ammon A, Baumann I, Talaska T, Schönberg A, Stöbel K, et al. Risk factors in Lyme borreliosis: a German case-control study. Int J Med Microbiol (2002) 291(Suppl 33):220. doi:10.1016/S1438-4221(02)80059-5

182. Horobik V, Keesing F, Ostfeld RS. Abundance and Borrelia burgdorferi - infection prevalence of nymphal Ixodes scapularis ticks along forest-field edges. Ecohealth (2007) 3:262-8. doi:10.1007/s10393-006-0065-1

183. Fish D. Environmental risk and prevention of Lyme disease. Am J Med (1995) 98(Suppl 4A):2-9. doi:10.1016/S0002-9343(99)80038-2

184. Zeman P, Januška J. Epizootiological background of dissimilar distribution of human cases of Lyme borreliosis and tick-borne encephalitis in a join endemic area. Comp Immunol Microbiol Infect Dis (1999) 22:247-60. doi:10.1016/S0147-9571(99)00015-6

185. Gray J. Risk assessment in Lyme borreliosis. Wien Klin Wochenschr (1999) 111:990-3.

186. Matuschka FR, Allgöver R, Spielman A, Richter D. Characteristics of garden dormice that contribute to their capacity as reservoirs for Lyme disease spirochetes. Appl Environ Microbiol (1999) 65(2):707-11.

187. Matuschka FR, Endepols S, Richter D, Ohlenbusch A, Eiffert H, Spielman A. Risk of urban Lyme disease enhanced by the presence of rats. J Infect Dis (1996) 174:1108-11. doi:10.1093/infdis/174.5.1108

188. Skuballa J, Oehme R, Hartelt K, Petney T, Buecher T, Kimmig P, et al. European hedgehogs as hosts for Borrelia spp., Germany. Emerg Infect Dis (2007) 13(6):952-3. doi:10.3201/eid1306.070224

189. Humair PF, Turrian N, Aeschlimann A, Gern L. Ixodes ricinus immatures on birds in a focus of Lyme borreliosis. Folia Parasitol (1993) 40:237-42.

190. Humair PF, Postic D, Wallich R, Gern L. An avian reservoir (Turdus merula) of the Lyme borreliosis spirochaetes. Zentralbl Bakteriol (1998) 287: $521-38$.

191. Dubska L, Literak I, Kocianova E, Taragelova V, Sychra O. Differential role of passerine birds in distribution of Borrelia spirochetes, based on data from ticks collected from birds during the postbreeding migration period in Central Europe. Appl Environ Microbiol (2009) 75(3):596-602. doi:10.1128/AEM. 01674-08

192. Dubska L, Literak I, Kocianova E, Taragelova V, Sverakova V, Sychra O, et al. Synanthropic birds influence the distribution of Borrelia species: analysis of Ixodes ricinus ticks feeding on passerine birds. Appl Environ Microbiol (2011) 77(3):1115-7. doi:10.1128/AEM.02278-10

193. Kurtenbach K, De Michelis S, Etti S, Schäfer SM, Sewell H-S, Brade V, et al. Host association of Borrelia burgdorferi sensu lato - the key role of host complement. Trends Microbiol (2002) 10:74-9. doi:10.1016/S0966-842X(01)02298-3
194. Kurtenbach K, Carey D, Hoodless AN, Nuttall PA, Randolph SE. Competence of pheasants as reservoirs for Lyme disease spirochetes. J Med Entomol (1998) 35:77-81.

195. Heylen D, Tijsse E, Fonville M, Matthysen E, Sprong H. Transmission dynamics of Borrelia burgdorferi s.l. in a bird tick community. Environ Microbiol (2013) 15:663-73. doi:10.1111/1462-2920.12059

196. Lane R, Loye J. Lyme disease in California: interrelationship of ixodid ticks (Acari), rodents, and Borrelia burgdorferi. J Med Entomol (1989) 28:719-25.

197. Hubálek Z, Halouzka J, Juricová Z. Investigation of haematophagous arthropods for Borreliae - summarized data, 1988-1996. Folia Parasitol (1998) 45:67-72.

198. Pospíšil L, Pejcoch M, Zahrádková S. Findings of Borreliae in ixodid ticks of South-Moravian region [In Czech: Nálezy borelií v klišstatech v jihomoravském regionu]. Prakt Lék (1992) 72:163-5.

199. Doby JM, Degeilh B. Borreliose de Lyme et parcs publics urbaines et periurbaines. Bull Soc Sci Nat Ouest France (1996) 18(1):34-40.

200. Georgieva G, Tasseva E, Gergova S, Panova M, Gaidajiev I. Study of the ixodid ticks (Acarina, Ixodidae) for Borrelia harbouring in Sofia and surroundings: II. Study of the number and Borrelia harbouring in ungorged Ixodes ricinus ticks in parks of Sofia city. Dokl Bulgarsk Akad Nauk (1999) 52(11-12):125-8.

201. Rajkovic DV, Jurisic AD. Ixodes ricinus as vector and reservoir of Borrelia burgdorferi in an urban environment. Arch Biol Sci (2005) 57:13-4. doi:10.2298/ABS0503253R

202. Jarošová V, Rudolf I, Halouzka J, Hubálek Z. Borrelia burgdorferi sensu lato in ixodid ticks from Ostrava slag heaps. [In Czech: Borrelia burgdorferi s.l. v klišs tatech na ostravských haldách]. Epidemiol Mikrobiol Imunol (2009) 58:90-7.

203. Hubálek Z, Halouzka J. Prevalence rates of Borrelia burgdorferi sensu lato in host-seeking Ixodes ricinus ticks in Europe. Parasitol Res (1998) 84:167-72. doi:10.1007/s004360050378

204. Pokorný P. Borrelia sp. in ticks (Ixodes ricinus) on the territory of the capital of Prague. [In Czech: Borrelia sp. v klíšteti obecném (Ixodes ricinus) na území mesta Prahy]. Ceskosl Epidemiol Mikrobiol Imunol (1990) 39:32-8.

205. Plch J, Bašta J. Incidence of spirochetes (Borrelia sp.) in the tick Ixodes ricinus in the urban environment (capital of Prague) between 1994-1997. Zentralbl Bakteriol (1999) 289:79-88. doi:10.1016/S0934-8840(99)80127-3

206. Bašta J, Plch J, Hulínská D, Daniel M. Incidence of Borrelia garinii and Borrelia afzelii in Ixodes ricinus ticks in an urban environment, Prague, Czech Republic, between 1995 and 1998. Eur J Clin Microbiol Infect Dis (1999) 18:515-7. doi:10.1007/s100960050335

207. Pokorný P, Zahrádková S. Incidence of Borrelia in the common tick (Ixodes ricinus) in the area of the city of Brno. [In Czech: Výskyt borrelií v kliśsteti obecném (Ixodes ricinus) na území mesta Brna]. Ceskosl Epidemiol Mikrobiol Imunol (1990) 39:166-70.

208. Hubálek Z, Halouzka J, Juricová Z. Prevalence of borreliae in Ixodes ricinus ticks from urban parks. Folia Parasitol (1993) 40:236.

209. Žákovská A, Šerý O, Pejchalová K, Horváth R, Janouškovcová E, Halouzka J. Monitoring of presence of Borrelia burgdorferi sensu lato in Ixodes ricinus ticks in park Pisárky (Brno) in 1996-1998: dark-field microscopy and PCR method. In: Kazimírová M, Labuda M, Nuttall PA, editors. Proceeding on the 3rd International Conference "Ticks and Tick-borne Pathogens: Into the 21st Century". Bratislava: Polygrafia SAV (2000). p. 97-103.

210. Pejchalova K, Zakovska A, Mejzlikova M, Halouzka J, Dendis M. Isolation, cultivation and identification of Borrelia burgdorferi genospecies from Ixodes ricinus ticks from the city of Brno, Czech Republic. Ann Agric Environ Med (2007) 14:75-9.

211. Reis C, Cote M, Paul REL, Bonnet S. Questing ticks in suburban forest are infected by at least six tick-borne pathogens. Vector Borne Zoonotic Dis (2011) 11:907-16. doi:10.1089/vbz.2010.0103

212. Kahl O, Schmidt K, Schönberg A, Laukammjosten U, Knülle W, Bienzle U. Prevalence of Borrelia burgdorferi in Ixodes ricinus ticks in Berlin (West). Zentralbl Bakteriol (1989) 270:434-40.

213. Hornok S, Meli ML, Gönczi E, Halász E, Takács N, Farkas R, et al. Occurrence of ticks and prevalence of Anaplasma phagocytophilum and Borrelia burgdorferi s.l. in three types of urban biotopes: forests, parks and cemeteries. Ticks Tick Borne Dis (2014) 5:785-9. doi:10.1016/j.ttbdis.2014.05.010

214. Corrain R, Drigo M, Fenati M, Menandro ML, Mondin A, Pasotto D, et al. Study on ticks and tick-borne zoonoses in public parks in Italy. Zoonoses Public Health (2012) 59:468-76. doi:10.1111/j.1863-2378.2012.01490.x 
215. Žygutienė M, Alekseev A, Dubinina H, Kazlauskienȧ R. Evidence for a risk of tick-borne infection in the city parks of Vilnius, Lithuania. Ekologija (2008) 54(1):40-3. doi:10.2478/V10055-008-0008-y

216. Stanczak J, Gabre RM, Kruminis-Lozowska W, Racewicz M, Kubica-Biernat B. Ixodes ricinus as a vector of Borrelia burgdorferi sensu lato, Anaplasma phagocytophilum and Babesia microti in urban and suburban forests. Ann Agric Environ Med (2004) 11:109-14.

217. Kosik-Bogacka D, Kuzna-Grygiel W, Bukowska K. The prevalence of spirochete Borrelia burgdorferi sensu lato in ticks Ixodes ricinus and mosquitoes Aedes spp. within a selected recreational area in the city of Szczecin. Ann Agric Environ Med (2004) 11:105-8.

218. Sinski E, Rijpkema SG. Prevalence of Borrelia burgdorferi infection in Ixodes ricinus ticks at urban and suburban forest habitats. [In Polish: Wystepowanie zakazenia Borrelia burgdorferi s.l. u kleszczy Ixodes ricinus w miejskim i podmiejskim biotopie lesnym]. Przegl Epidemiol (1997) 51:431-5.

219. Chmielewski T, Andrzejewski K, Maczka I, Fiecek B, Radlinska M, TylewskaWierzbanowska S. Ticks infected with bacteria pathogenic to humans in municipal parks in Warsaw. [In Polish: Kleszcze zakazone bakteriami chorobotworczymi dla czlowieka na terenach parkow miejskich Warszawy]. Przegl Epidemiol (2011) 65:577-81.

220. Cekanac R, Pavlovic N, Gledovic Z, Grgurevic A, Stajkovic N, Lepsanovic Z, et al. Prevalence of Borrelia burgdorferi in Ixodes ricinus ticks in Belgrade area. Vector Borne Zoonotic Dis (2012) 10:447-52. doi:10.1089/vbz.2009.0139

221. Kmety E, Řeháček J, Výrosteková V, Kocianová E, Guryčová D. Infection rate of ticks with Borrelia burgdorferi and Francisella tularensis in Slovakia. [In Slovak: Štúdium premorenosti klieštov boréliou burgdorferi a francisellou tularensis na Slovensku]. Bratisl Lek Listy (1990) 91:251-66.

222. Pet'ko B, Peterková J, Tresová G, Prokopčáková H, Čisláková L, Stanko M. Seasonal prevalence of Borrelia burgdorferi in Ixodes ricinus ticks in Košice park forest. In: Venglovský J, Juriš P, Ondrašovic M, Sokol J, editors. Hygienic and Ecological Problems in Relation to Veterinary Medicine. Košice (1996).p. 213-20.

223. Pangrácová L, Derdáková M, Pekárik L, Hviščová I, Vichová $\mathrm{B}$, Stanko $\mathrm{M}$, et al. Ixodes ricinus abundance and its infection with the tick-borne pathogens in urban and suburban areas of Eastern Slovakia. Parasit Vectors (2013) 6:238. doi:10.1186/1756-3305-6-238

224. Cathomas F. Vorkommen von Ixodes ricinus und Borrelia burgdorferi sensu lato in städtischen Naherholungsgebieten am Beispiel von Basel (Schweiz). Mitt Naturforsch Ges Basel (2005) 8:63-79.

225. Guy EC, Farquhar RG. Borrelia burgdorferi in urban parks. Lancet (1991) 338:253. doi:10.1016/0140-6736(91)90392-3

226. Smith G, Wileyto EP, Hopkins RB, Cherry BR, Maher JP. Risk factors for Lyme disease in Chester County, Pennsylvania. Public Health Rep (2001) 116(Suppl 1):146-56. doi:10.1093/phr/116.S1.146

227. Mavin S, Hopkins PC, MacLennan A, Joss AWL, Do HY. Urban and rural risks of Lyme disease in the Scottish Highlands. Scott Med J (2009) 54:24-6. doi:10.1258/rsmsmj.54.2.24

228. Zeman P, Benes C. Peri-urbanisation, counter-urbanisation, and an extension of residential exposure to ticks: a clue to the trends in Lyme borreliosis incidence in the Czech Republic? Ticks Tick Borne Dis (2014) 5:907-16. doi:10.1016/j.ttbdis.2014.07.006

229. Foggie A. Studies on the infectious agent of tick borne fever in sheep. J Pathol Bacteriol (1951) 63:1-15. doi:10.1002/path.1700630103

230. Gribble DH. Equine ehrlichiosis. J Am Vet Med Assoc (1969) 155:462-9.

231. Chen SM, Dumler JS, Bakken JS, Walker DH. Identification of a granulocytotropic Ehrlichia species as the etiologic agent of human disease. J Clin Microbiol (1994) 32(3):589-95.

232. Dumler JS, Barbet AF, Bekker CP, Dasch GA, Palmer GH, Ray SC, et al. Reorganization of genera in the families Rickettsiaceae and Anaplasmataceae in the order Rickettsiales: unification of some species of Ehrlichia with Anaplasma, Cowdria with Ehrlichia and Ehrlichia with Neorickettsia, descriptions of six new species combinations and designation of Ehrlichia equi and 'HGE agent' as subjective synonyms of Ehrlichia phagocytophila. Int J Syst Evol Microbiol (2001) 51(6):2145-65. doi:10.1099/00207713-51-6-2145

233. Heikkilä HM, Bondarenko A, Mihalkov A, Pfister K, Spillmann T. Anaplasma phagocytophilum infection in a domestic cat in Finland: case report. Acta Vet Scand (2010) 52:62. doi:10.1186/1751-0147-52-62

234. Kohn B, Galke D, Beelitz P, Pfister K. Clinical features of canine granulocytic anaplasmosis in 18 naturally infected dogs. J Vet Intern Med (2008) 22(6):1289-95. doi:10.1111/j.1939-1676.2008.0180.x
235. Petrovec M, Lotric Furlan S, Zupanc TA, Strle F, Brouqui P, Roux V, et al. Human disease in Europe caused by a granulocytic Ehrlichia species. J Clin Microbiol (1997) 35(6):1556-9.

236. Edouard S, Koebel C, Goehringer F, Socolovschi C, Jaulhac B, Raoult D, et al. Emergence of human granulocytic anaplasmosis in France. Ticks Tick Borne Dis (2012) 3(5-6):403-5. doi:10.1016/j.ttbdis.2012.10.002

237. Lotrič-Furlan S, Petrovec M, Županc TA, Nicholson WL, Sumner JW, Childs JE, et al. Human granulocytic ehrlichiosis in Europe: clinical and laboratory findings for four patients from Slovenia. Clin Infect Dis (1998) 27:424-8. doi:10.1086/514683

238. van Dobbenburgh A, van Dam AP, Fikrig E. Human granulocytic ehrlichiosis in Western Europe. N Engl J Med (1999) 340:1214-6. doi:10.1056/ NEJM199904153401517

239. Arnez M, Petrovec M, Lotric-Furlan S, Županc TA, Strle F. First European pediatric case of human granulocytic ehrlichiosis. J Clin Microbiol (2001) 39:4591-2. doi:10.1128/JCM.39.12.4591-4592.2001

240. Karlsson U, Bjoersdorff A, Massung RF, Christensson B. Human granulocytic ehrlichiosis - a clinical case in Scandinavia. Scand J Infect Dis (2001) 33:73-4. doi:10.1080/003655401750064130

241. Oteo JA, Blanco JR, Martínez de Artola V, Ibarra V. First report of human granulocytic ehrlichiosis from southern Europe (Spain). Emerg Infect Dis (2000) 6:430-2. doi:10.3201/eid0604.000425

242. Bakken JS, Dumler JS. Clinical diagnosis and treatment of human granulocytotropic anaplasmosis. Ann N Y Acad Sci (2006) 1078:236-47. doi:10.1196/ annals. 1374.042

243. Blanco JR, Oteo JA. Human granulocytic ehrlichiosis in Europe. Clin Microbiol Infect (2002) 8:763-72. doi:10.1046/j.1469-0691.2002.00557.x

244. Tylewska-Wierzbanowska S, Chmielewski T, Kondrusik M, HermanowskaSzpakowicz T, Sawicki W, Sulek K. First cases of acute human granulocytic ehrlichiosis in Poland. Eur J Clin Microbiol Infect Dis (2001) 20:196-8. doi:10.1007/s100960100464

245. Walder G, Falkensammer B, Aigner J, Tiwald G, Dierich MP, Wurzner R, et al. First documented case of human granulocytic ehrlichiosis in Austria. Wien Klin Wochenschr (2003) 115:263-6. doi:10.1007/BF03040326

246. Doudier B, Olano J, Parola P, Brouqui P. Factors contributing to emergence of Ehrlichia and Anaplasma spp. as human pathogens. Vet Parasitol (2010) 167:149-54. doi:10.1016/j.vetpar.2009.09.016

247. Haschke-Becher E, Bernauer R, Walleczek AM, Apfalter P, Afazel-Saeedi S, Kraus J, et al. First detection of the Anaplasma phagocytophilum groEL-A genotype in man. J Infect (2010) 60:300-5. doi:10.1016/j.jinf.2009.12.010

248. Koebel C, Kern A, Edouard S, Hoang AT, Celestin N, Hansmann Y, et al. Human granulocytic anaplasmosis in eastern France: clinical presentation and laboratory diagnosis. Diagn Microbiol Infect Dis (2012) 72(3):214-8. doi:10.1016/j.diagmicrobio.2011.12.005

249. Misic-Majerus L, Bujic N, Madaric V, Avsic-Županc T, Milinkovic S. [Human anaplasmosis (ehrlichiosis)]. Acta Med Croatica (2006) 60:411-9.

250. Nováková M, Víchová B, Majlathová V, Lesnáková A, Pochybová M, Pet’ko B. First case of human granulocytic anaplasmosis from Slovakia. Ann Agric Environ Med (2010) 17:173-5.

251. Vogl UM, Presterl E, Stanek G, Ramharter M, Gattringer KB, Graninger W. First described case of human granulocytic anaplasmosis in a patient in Eastern Austria. Wien Med Wochenschr (2010) 160:91-3. doi:10.1007/s10354-009-0733-1

252. Vanicek J, Stastnik M, Kianicka B, Bares M, Bulik M. Rare neurological presentation of human granulocytic anaplasmosis. Eur J Neurol (2013) 20(5):e70-2. doi:10.1111/ene.12110

253. Jin H, Wei F, Liu Q, Qian J. Epidemiology and control of human granulocytic anaplasmosis: a systematic review. Vector Borne Zoonotic Dis (2012) 12(4):269-74. doi:10.1089/vbz.2011.0753

254. Hulínská D, Langrová K, Pejcoch M, Pavlásek I. Detection of Anaplasma phagocytophilum in animals by real-time polymerase chain reaction. APMIS (2004) 112:239-47. doi:10.1111/j.1600-0463.2004.apm11204-0503.x

255. Scharf W, Schauer S, Freyburger F, Petrovec M, Schaarschmidt-Kiener D, Liebisch G, et al. Distinct host species correlate with Anaplasma phagocytophilum ankA gene clusters. J Clin Microbiol (2011) 49:790-6. doi:10.1128/ JCM.02051-10

256. Zeman P, Pecha M. Segregation of genetic variants of Anaplasma phagocytophilum circulating among wild ruminants within a Bohemian forest (Czech Republic). Int J Med Microbiol (2008) 298:203-10. doi:10.1016/j.ijmm.2008. 03.003 
257. Silaghi C, Pfister K, Overzier E. Molecular investigation for bacterial and protozoan tick-borne pathogens in wild boars (Sus scrofa) from southern Germany. Vector Borne Zoonotic Dis (2014) 14(5):371-3. doi:10.1089/vbz.2013.1495

258. Michalik J, Stanczak J, Cieniuch S, Racewicz M, Sikora B, Dabert M. Wild boars as hosts of human-pathogenic Anaplasma phagocytophilum variants. Emerg Infect Dis (2012) 18(6):998-1001. doi:10.3201/eid1806.110997

259. Alberti A, Zobba R, Chessa B, Addis MF, Sparagano O, Pinna Parpaglia $\mathrm{ML}$, et al. Equine and canine Anaplasma phagocytophilum strains isolated on the island of Sardinia (Italy) are phylogenetically related to pathogenic strains from the United States. Appl Environ Microbiol (2005) 71(10):6418-22. doi:10.1128/AEM.71.10.6418-6422.2005

260. Silaghi C, Liebisch G, Pfister K. Genetic variants of Anaplasma phagocytophilum from 14 equine granulocytic anaplasmosis cases. Parasit Vectors (2011) 4:161. doi:10.1186/1756-3305-4-161

261. Silaghi C, Hamel D, Thiel C, Pfister K, Passos LM, Rehbein S. Genetic variants of Anaplasma phagocytophilum in wild caprine and cervid ungulates from the Alps in Tyrol, Austria. Vector Borne Zoonotic Dis (2011) 11(4):355-62. doi:10.1089/vbz.2010.0051

262. Huhn C, Winter C, Wolfsperger T, Wüppenhorst N, Strašek Smrdel K, Skuballa J, et al. Analysis of the population structure of Anaplasma phagocytophilum using multilocus sequence typing. PLoS One (2014) 9(4):e93725. doi:10.1371/journal.pone.0093725

263. Hagedorn P, Imhoff M, Fischer C, Domingo C, Niedrig M. Human granulocytic anaplasmosis acquired in Scotland, 2013. Emerg Infect Dis (2014) 20(6):1079-81. doi:10.3201/eid2006.131849

264. Glatz M, Müllegger RR, Maurer F, Fingerle V, Achermann Y, Wilske B, et al. Detection of Candidatus Neoehrlichia mikurensis, Borrelia burgdorferi sensu lato genospecies and Anaplasma phagocytophilum in a tick population from Austria. Ticks Tick-Borne Dis (2014) 5:139-44. doi:10.1016/j.ttbdis.2013. 10.006

265. Derdáková M, Václav R, Pangrácová-Blaňárová L, Selyemová D, Koči J, Walder $\mathrm{G}$, et al. Candidatus Neoehrlichia mikurensis and its co-circulation with Anaplasma phagocytophilum in Ixodes ricinus ticks across ecologically different habitats of Central Europe. Parasit Vectors (2014) 7:160. doi:10.1186/17563305-7-160

266. Venclikova K, Rudolf I, Mendel J, Betasova L, Hubalek Z. Rickettsiae in questing Ixodes ricinus ticks in the Czech Republic. Ticks Tick Borne Dis (2014) 5(2):135-8. doi:10.1016/j.ttbdis.2013.09.008

267. May K, Strube C. Prevalence of Rickettsiales (Anaplasma phagocytophilum and Rickettsia spp.) in hard ticks (Ixodes ricinus) in the city of Hamburg, Germany. Parasitol Res (2014) 113(6):2169-75. doi:10.1007/s00436-014-3869-x

268. Tappe J, Strube C. Anaplasma phagocytophilum and Rickettsia spp. infections in hard ticks (Ixodes ricinus) in the city of Hanover (Germany): revisited. Ticks Tick Borne Dis (2013) 4(5):432-8. doi:10.1016/j.ttbdis.2013.04.009

269. Schorn S, Pfister K, Reulen H, Mahling M, Manitz J, Thiel C, et al. Prevalence of Anaplasma phagocytophilum in Ixodes ricinus in Bavarian public parks, Germany. Ticks Tick Borne Dis (2011) 2:196-203. doi:10.1016/j.ttbdis.2011.09.009

270. Silaghi C, Gilles J, Höhle M, Fingerle V, Just FT, Pfister K. Anaplasma phagocytophilum infection in Ixodes ricinus, Bavaria, Germany. Emerg Infect Dis (2008) 14:972-4. doi:10.3201/eid1406.061513

271. Overzier E, Pfister K, Thiel C, Herb I, Mahling M, Silaghi C. Anaplasma phagocytophilum in questing Ixodes ricinus ticks: comparison of prevalences and partial 16S rRNA gene variants in urban, pasture, and natural habitats. Appl Environ Microbiol (2013) 79(5):1730-4. doi:10.1128/AEM.03300-12

272. Schicht S, Junge S, Schnieder T, Strube C. Prevalence of Anaplasma phagocytophilum and coinfection with Borrelia burgdorferi sensu lato in the hard tick Ixodes ricinus in the city of Hanover (Germany). Vector Borne Zoonotic Dis (2011) 11(12):1595-7. doi:10.1089/vbz.2011.0699

273. Sytykiewicz H, Karbowiak G, Hapunik J, Szpechcinski A, Supergan-Marwicz M, Goławska S, et al. Molecular evidence of Anaplasma phagocytophilum and Babesia microti co-infections in Ixodes ricinus ticks in central-eastern region of Poland. Ann Agric Environ Med (2012) 19(1):45-9.

274. Víchová $B$, Majláthová V, Nováková $M$, Stanko $M$, Hvišcová I, Pangrácová $L$, et al. Anaplasma infections in ticks and reservoir hosts from Slovakia. Infect Genet Evol (2014) 22:265-72. doi:10.1016/j.meegid.2013.06.003

275. Kawahara M, Rikihisa Y, Isogai E, Takahashi M, Misumi H, Suto C, et al. Ultrastructure and phylogenetic analysis of 'Candidatus Neoehrlichia mikurensis' in the family Anaplasmataceae, isolated from wild rats and found in Ixodes ovatus ticks. Int J Syst Evol Microbiol (2004) 54:1837-43. doi:10.1099/ijs.0.63260-0
276. Schouls LM, Van De Pol I, Rijpkema SG, Schot CS. Detection and identification of Ehrlichia, Borrelia burgdorferi sensu lato, and Bartonella species in Dutch Ixodes ricinus ticks. J Clin Microbiol (1999) 37:2215-22.

277. Alekseev AN, Dubinina HV, Van De Pol I, Schouls LM. Identification of Ehrlichia sp and Borrelia burgdorferi in Ixodes ticks in the Baltic regions of Russia. J Clin Microbiol (2001) 39:2237-42. doi:10.1128/JCM.39.6.2237-2242. 2001

278. Sanogo YO, Parola P, Shpynov S, Camicas JL, Brouqui P, Caruso G, et al. Genetic diversity of bacterial agents detected in ticks removed from asymptomatic patients in northeastern Italy. Ann N Y Acad Sci (2003) 990:182-90. doi:10.1111/j.1749-6632.2003.tb07360.x

279. von Loewenich FD, Baumgarten BU, Schröppel K, Geissdörfer W, Röllinghoff M, Bogdan C. High diversity of ankA sequences of Anaplasma phagocytophilum among Ixodes ricinus ticks in Germany. J Clin Microbiol (2003) 41:5033-40. doi:10.1128/JCM.41.11.5033-5040.2003

280. Pan HUA, Liu S, Ma Y, Tong S, Sun Y. Ehrlichia-like organism gene found in small mammals in the suburban district of Guangzhou of China. Ann NYAcad Sci (2003) 990:107-11. doi:10.1111/j.1749-6632.2003.tb07346.x

281. Jahfari S, Fonville M, Hengeveld P, Reusken C, Scholte EJ, Takken W, et al. Prevalence of Neoehrlichia mikurensis in ticks and rodents from North-west Europe. Parasit Vectors (2012) 5:74. doi:10.1186/1756-3305-5-74

282. Richter D, Matuschka FR. “Candidatus Neoehrlichia mikurensis,” Anaplasma phagocytophilum, and Lyme disease spirochetes in questing European vector ticks and in feeding ticks removed from people. J Clin Microbiol (2012) 50:943-7. doi:10.1128/JCM.05802-11

283. Movila A, Toderas I, Uspenskaia I, Conovalov J. Molecular detection of tickborne pathogens in Ixodes ricinus from Moldova collected in 1960. Ticks Tick Borne Dis (2013) 4:359-61. doi:10.1016/j.ttbdis.2012.12.004

284. Richter D, Kohn C, Matuschka FR. Absence of Borrelia sp, Candidatus Neoehrlichia mikurensis, and Anaplasma phagocytophilum in questing adult Dermacentor reticulatus ticks. Parasitol Res (2013) 112:107-11. doi:10.1007/ s00436-012-3110-8

285. Fertner ME, Mølbak L, Boye Pihl TP, Fomsgaard A, Bødker R. First detection of tick-borne "Candidatus Neoehrlichia mikurensis" in Denmark 2011. Euro Surveill (2012) 17(8):20096.

286. Hornok S, Meli ML, Gönczi E, Hofmann-Lehmann R. First evidence of Candidatus Neoehrlichia mikurensis in Hungary. Parasit Vectors (2013) 6:267. doi:10.1186/1756-3305-6-267

287. Capelli G, Ravagnan S, Montarsi F, Ciocchetta S, Cazzin S, Porcellato E, et al. Occurrence and identification of risk areas of Ixodes ricinus-borne pathogens: a cost-effectiveness analysis in north-eastern Italy. Parasit Vectors (2012) 5:61. doi:10.1186/1756-3305-5-61

288. van Overbeek L, Gassner F, van der Plas CL, Kastelein P, Nunes-da Rocha U, Takken W. Diversity of Ixodes ricinus tick-associated bacterial communities from different forests. FEMS Microbiol Ecol (2008) 66:72-84. doi:10.1111/j. 1574-6941.2008.00468.x

289. Coipan EC, Jahfari S, Fonville M, Maassen CB, van der Giessen J, Takken $\mathrm{W}$, et al. Spatiotemporal dynamics of emerging pathogens in questing Ixodes ricinus. Front Cell Infect Microbiol (2013) 3:36. doi:10.3389/fcimb.2013. 00036

290. Špitalská E, Boldiš V, Košt'anová Z, Kocianová E, Štefanidesová K. Incidence of various tick-borne microorganisms in rodents and ticks of central Slovakia. Acta Virol (2008) 52:175-9.

291. Palomar AM, García-Álvarez L, Santibáñez S, Portillo A, Oteo JA. Detection of tick-borne 'Candidatus Neoehrlichia mikurensis' and Anaplasma phagocytophilum in Spain in 2013. Parasit Vectors (2014) 7:57. doi:10.1186/1756-33057-57

292. Andersson M, Bartkova S, Lindestad O, Raberg L. Co-infection with 'Candidatus Neoehrlichia mikurensis' and Borrelia afzelii in Ixodes ricinus ticks in southern Sweden. Vector Borne Zoonotic Dis (2013) 13:438-42. doi:10.1089/ vbz.2012.1118

293. Lommano E, Bertaiola L, Dupasquier C, Gern L. Infections and co-infections of questing Ixodes ricinus ticks by emerging zoonotic pathogens in Western Switzerland. Appl Environ Microbiol (2012) 78:4606-12. doi:10.1128/AEM. 07961-11

294. Maurer FP, Keller PM, Beuret C, Johab C, Achermann Y, Gubler J, et al. Close geographic association of human neoehrlichiosis and tick populations carrying Candidatus Neoehrlichia mikurensis in Eastern Switzerland. J Clin Microbiol (2013) 51:169-76. doi:10.1128/JCM.01955-12 
295. Vayssier-Taussat M, Le Rhun D, Buffet JP, Maaoui N, Galan M, Guivier E, et al. Candidatus Neoehrlichis mikurensis in bank voles, France. Emerg Infect Dis (2012) 12:2063-5. doi:10.3201/eid1812.120846

296. Andersson M, Raberg L. Wild rodents and novel human pathogen Candidatus Neoehrlichia mikurensis, Southern Sweden. Emerg Infect Dis (2011) 17:1716-8. doi:10.3201/eid1709.101058

297. Diniz PP, Schulz BS, Hartmann K, Breitschwerdt EB. “Candidatus Neoehrlichia mikurensis” infection in a dog from Germany. J Clin Microbiol (2011) 49:2059-62. doi:10.1128/JCM.02327-10

298. Kamani J, Baneth G, Mumcuoglu KY, Waziri NE, Eyal O, Guthmann Y, et al. Molecular detection and characterization of tick-borne pathogens in dogs and ticks from Nigeria. PLoS Negl Trop Dis (2013) 7(3):e2108. doi:10.1371/journal. pntd.0002108

299. Tijsse-Klasen E, Koopmans MPG, Sprong H. Tick-borne pathogen - reversed and conventional discovery of disease. Front Public Health (2014) 2:73. doi:10.3389/fpubh.2014.00073

300. Fehr JS, Bloemberg GV, Ritter C, Hombach M, Lüscher TF, Weber R, et al. Septicemia caused by tick-borne bacterial pathogen Candidatus Neoehrlichia mikurensis. Emerg Infect Dis (2010) 16:1127-9. doi:10.3201/eid1607.091907

301. von Loewenich FD, Geissdorfer W, Disque C, Matten J, Schett G, Sakka SG, et al. Detection of "Candidatus Neoehrlichia mikurensis" in two patients with severe febrile illnesses: evidence for a European sequence variant. J Clin Microbiol (2010) 48:2630-5. doi:10.1128/JCM.00588-10

302. Welinder-Olsson C, Kjellin E, Vaht K, Jacobsson S, Wenneras C. First case of human "Candidatus Neoehrlichia mikurensis" infection in a febrile patient with chronic lymphocytic leukemia. J Clin Microbiol (2010) 48:1956-9. doi:10.1128/JCM.02423-09

303. Peková S, Vydra J, Kabicková H, Frankova S, Haugvicova R, Mazal O, et al. Candidatus Neoehrlichia mikurensis infection identified in 2 hematooncologic patients: benefit of molecular techniques for rare pathogen detection. Diagn Microbiol Infect Dis (2011) 69:266-70. doi:10.1016/j.diagmicrobio.2010.10.004

304. Rar V, Golovljova I. Anaplasma, Ehrlichia, and "Candidatus Neoehrlichia" bacteria: pathogenicity, biodiversity, and molecular genetic characteristics, a review. Infect Genet Evol (2011) 11:1842-61. doi:10.1016/j.meegid.2011.09.019

305. Raoult D, Roux V. Rickettsioses as paradigms of new or emerging infectious diseases. Clin Microbiol Rev (1997) 10:694-719.

306. Radulovic S, Feng HM, Morovic M, Djelalija B, Popov V, Crocquet-Valdes $\mathrm{P}$, et al. Isolation of Rickettsia akari from a patient in a region where Mediterranean spotted fever is endemic. Clin Infect Dis (1996) 22:216-20. doi:10.1093/clinids/22.2.216

307. Blanco JR, Oteo JA. Rickettsiosis in Europe. Ann N Y Acad Sci (2006) 1078:26-33. doi:10.1196/annals.1374.003

308. Oteo JA, Portillo A. Tick-borne rickettsioses in Europe. Ticks Tick Borne Dis (2012) 3:271-8. doi:10.1016/j.ttbdis.2012.10.035

309. Sréter-Lancz Z, Széll Z, Kovács G, Egyed L, Márialigeti K, Sréter T. Rickettsiae of the spotted-fever group in ixodid ticks from Hungary: identification of a new genotype ('Candidatus Rickettsia kotlanii'). Ann Trop Med Parasitol (2006) 100:229-36. doi:10.1179/136485906X91468

310. Mura A, Masala G, Tola S, Satta G, Fois F, Piras P, et al. First direct detection of rickettsial pathogens and a new rickettsia, 'Candidatus Rickettsia barbariae', in ticks from Sardinia, Italy. Clin Microbiol Infect (2008) 14:1028-33. doi:10.1111/j.1469-0691.2008.02082.x

311. Palomar AM, Portillo A, Santibánez P, Santibánez S, García-Álvarez L, Oteo JA. Genetic characterization of Candidatus Rickettsia vini. A new Rickettsia amplified in ticks from La Rioja, Spain. Ticks Tick Borne Dis (2012) 3:318-20. doi:10.1016/j.ttbdis.2012.10.025

312. Parola $P$, Raoult D. Ticks and tickborne bacterial diseases in humans: an emerging infectious threat. Clin Infect Dis (2001) 32:897-928. doi:10.1086/319347

313. Fernandez-Soto P, Perez-Sanchez R, Diaz Martin V, Encinas-Grandes A, Alamo Sanz R, Perez-Sanchez R, et al. Rickettsia massiliae in ticks removed from humans in Castilla y Leon, Spain. Eur J Clin Microbiol Infect Dis (2006) 25:811-3. doi:10.1007/s10096-006-0217-9

314. Elfving K, Olsen B, Bergstrom S, Waldenstrom J, Lundkvist A, Sjostedt A, et al. Dissemination of spotted fever rickettsia agents in Europe by migrating birds. PLoS One (2010) 5:e8572. doi:10.1371/journal.pone.0008572

315. Burgdorfer W, Aeschlimann A, Peter O, Hayes SF, Philip RN. Ixodes ricinus: vector of a hitherto undescribed spotted fever group agent in Switzerland. Acta Trop (1979) 36:357-67.
316. Beati L, Raoult L. Rickettsiae massiliae sp. nov., a new spotted fever group rickettsia. Int Syst Bacteriol (1993) 43:839-40. doi:10.1099/0020771343-3-521

317. Dobec M, Golubic D, Punda-Polic V, Kaeppeli F, Sievers M. Rickettsia helvetica in Dermacentor reticulatus ticks. Emerg Infect Dis (2009) 15:98-100. doi:10.3201/eid1501.080815

318. Sprong H, Wielinga PR, Fonville M, Reusken C, Brandenburg AH, Borgsteede $\mathrm{F}$, et al. Ixodes ricinus ticks are reservoir hosts for Rickettsia helvetica and potentially carry flea-borne Rickettsia species. Parasit Vectors (2009) 2:41. doi:10.1186/1756-3305-2-41

319. Franke J, Meier F, Moldenhauer A, Straube E, Dorn W, Hildebrandt A. Established and emerging pathogens in Ixodes ricinus ticks collected from birds on a conservation island in the Baltic Sea. Med Vet Entomol (2010) 24:425-32. doi:10.1111/j.1365-2915.2010.00905.x

320. Kantso B, Svendsen CB, Jensen PM, Vennestrom J, Krogfelt KA. Seasonal and habitat variation in the prevalence of Rickettsia helvetica in Ixodes ricinus ticks from Denmark. Ticks Tick Borne Dis (2010) 1:101-3. doi:10.1016/j.ttbdis.2010. 01.004

321. Silaghi C, Gilles J, Höhle M, Pradel I, Just FT, Fingerle V, et al. Prevalence of spotted fever group rickettsiae in Ixodes ricinus (Acari: Ixodidae) in southern Germany. J Med Entomol (2008) 45:948-55. doi:10.1603/0022-2585(2008) 45[948:POSFGR]2.0.CO;2

322. Silaghi C, Hamel D, Thiel C, Pfister K, Pfeffer M. Spotted fever group Rickettsiae in ticks, Germany. Emerg Infect Dis (2011) 17:890-2. doi:10.3201/eid1705. 101445

323. Overzier E, Pfister K, Thiel C, Herb I, Mahling M, Silaghi C. Diversity of Babesia and Rickettsia species in questing Ixodes ricinus: a longitudinal study in urban, pasture, and natural habitats. Vector Borne Zoonotic Dis (2013) 13:559-64. doi:10.1089/vbz.2012.1278

324. Milhano N, Lopes de Carvalho I, Alves AS, Arroube S, Soares J, Rodriguez P, et al. Coinfections of Rickettsia slovaca and Rickettsia helvetica with Borrelia lusitaniae in ticks collected in a Safari Park, Portugal. Ticks Tick Borne Dis (2010) 1:172-7. doi:10.1016/j.ttbdis.2010.09.003

325. Radulović Ž, Chochlakis D, Tomanović S, Milutinovic M, Tselentis Y, Psaroulaki A. First detection of spotted fever group Rickettsiae in ticks in Serbia. Vector Borne Zoonotic Dis (2011) 11:111-5. doi:10.1089/vbz.2009.0254

326. Špitalská E, Boldiš V, Derdáková M, Selyemová D, Rusňáková-Taragel'ová V. Rickettsial infection in Ixodes ricinus ticks in urban and natural habitats of Slovakia. Ticks Tick Borne Dis (2014) 5:161-5. doi:10.1016/j.ttbdis. 2013.10.002

327. Švehlová A, Berthová L, Sallay B, Boldiš V, Sparagano O, Špitalská E. Sympatric occurrence of Ixodes ricinus, Dermacentor reticulatus and Haemaphysalis concinna ticks and their pathogens Rickettsia and Babesia species in Slovakia. Ticks Tick Borne Dis (2014) 5:600-5. doi:10.1016/j.ttbdis.2014.04.010

328. Nilsson K, Lindquist O, Pahlson C. Association of Rickettsia helvetica with chronic perimyocarditis in sudden cardiac death. Lancet (1999) 354:1169-73. doi:10.1016/S0140-6736(99)04093-3

329. Nilsson K, Elfving K, Páhlson C. Rickettsia helvetica in patient with meningitis, Sweden 2006. Emerg Infect Dis (2010) 16:490-2. doi:10.3201/ eid1603.090184

330. Svendsen CB, Milman N, Andersen CB, Rasmussen EM, Thomsen VØ, Krogfelt KA. Is sarcoidosis a rickettsiosis? An archival study. Scand J Infect Dis (2011) 43:349-53. doi:10.3109/00365548.2011.554431

331. Fournier PE, Allombert C, Supputamongkol Y, Caruso G, Brouqui P, Raoult D. An eruptive fever associated with antibodies to Rickettsia helvetica in Europe and Thailand. J Clin Microbiol (2004) 42:816-8. doi:10.1128/JCM.42.2.816818.2004

332. Parola P, Paddock CD, Raoult D. Tick-borne rickettsioses around the world: emerging diseases challenging old concepts. Clin Microbiol Rev (2005) 18:719-56. doi:10.1128/CMR.18.4.719-756.2005

333. Simser JA, Palmer AT, Fingerle V, Wilske B, Kurtti TJ, Munderloh UG. Rickettsia monacensis sp. nov., a spotted fever group Rickettsia, from ticks (Ixodes ricinus) collected in a European city park. Appl Environ Microbiol (2002) 68:4559-66. doi:10.1128/AEM.68.9.4559-4566.2002

334. Sekeyová Z, Fournier PE, Rehácek J, Raoult D. Characterization of a new spotted fever group Rickettsia detected in Ixodes ricinus (Acari: Ixodidae) collected in Slovakia. J Med Entomol (2000) 37:707-13. doi:10.1603/00222585-37.5.707 
335. Sekeyová Z, Kovácová E, Fournier PE, Raoult D. Isolation and characterization of a new Rickettsia from Ixodes ricinus ticks collected in Slovakia. Ann N Y Acad Sci (2003) 990:54-6. doi:10.1111/j.1749-6632.2003.tb07336.x

336. Gargili A, Palomar AM, Midilli K, Portillo A, Kar S, Oteo JA. Rickettsia species in ticks removed from humans in Istanbul, Turkey. Vector Borne Zoonotic Dis (2012) 12:938-41. doi:10.1089/vbz.2012.0996

337. Jado I, Oteo JA, Aldamiz M, Gil H, Escudero R, Ibarra V, et al. Rickettsia monacensis and human disease, Spain. Emerg Infect Dis (2007) 13:1405-7. doi:10.3201/eid1309.060186

338. Madeddu G, Mancini F, Caddeo A, Ciervo A, Babudieri S, Maida I, et al. Rickettsia monacensis as cause of Mediterranean spotted fever-like illness, Italy. Emerg Infect Dis (2012) 18:702-4. doi:10.3201/eid1804.111583

339. Dantas-Torres F, Chomel BB, Otranto D. Ticks and tick-borne diseases: a one health perspective. Trends Parasitol (2012) 28:437-46. doi:10.1016/j.pt.2012. 07.003

340. Bonnet S, Michelet L, Moutailler S, Cheval J, Hébert C, Vayssier-Taussat M, et al. Identification of parasitic communities within European ticks using next-generation sequencing. PLoS Negl Trop Dis (2014) 8:e2753. doi:10.1371/ journal.pntd.0002753

341. Hildebrandt A, Gray JS, Hunfeld KP. Human babesiosis in Europe: what clinicians need to know. Infection (2013) 41:1057-72. doi:10.1007/s15010-0130526-8

342. Hunfeld KP, Hildebrandt A, Gray JS. Babesiosis: recent insights into an ancient disease. Int J Parasitol (2008) 38:1219-37. doi:10.1016/j.ijpara.2008. 03.001

343. Herwaldt BL, Caccio S, Gherlinzoni F, Aspock H, Slemenda SB, Piccaluga $\mathrm{PP}$, et al. Molecular characterization of a non-Babesia divergens organism causing zoonotic babesiosis in Europe. Emerg Infect Dis (2003) 9:942-8. doi:10.3201/eid0908.020748

344. Haselbarth K, Tenter AM, Brade V, Krieger G, Hunfeld KP. First case of human babesiosis in Germany - clinical presentation and molecular characterisation of the pathogen. Int J Med Microbiol (2007) 297:197-204. doi:10.1016/j.ijmm. 2007.01.002

345. Martinot M, Zadeh MM, Hansmann Y, Grawey I, Christmann D, Aguillon $\mathrm{S}$, et al. Babesiosis in immunocompetent patients, Europe. Emerg Infect Dis (2011) 17:114-6. doi:10.3201/eid1701.100737

346. Legrand A, Bignon A, Borel M, Zerbib P, Langlois J, Chambon JP, et al. [Perioperative management of asplenic patients]. Ann Fr Anesth Reanim (2005) 24:807-13. doi:10.1016/j.annfar.2005.05.002

347. Chauvin A, Moreau E, Bonnet S, Plantard O, Malandrin L. Babesia and its hosts: adaptation to long-lasting interactions as a way to achieve efficient transmission. Vet Res (2009) 40:37. doi:10.1051/vetres/2009020

348. Lempereur L, Wirtgen M, Nahayo A, Caron Y, Shiels B, Saegerman C, et al. Wild cervids are host for tick vectors of Babesia species with zoonotic capability in Belgium. Vector Borne Zoonotic Dis (2012) 12:275-80. doi:10.1089/vbz.2011. 0722

349. Duh D, Jelovsek M, Avsic-Zupanc T. Evaluation of an indirect fluorescence immunoassay for the detection of serum antibodies against Babesia divergens in humans. Parasitology (2007) 134:179-85. doi:10.1017/S0031182006001387

350. Duh D, Petrovec M, Bidovec A, Avsic-Zupanc T. Cervids as Babesiae hosts, Slovenia. Emerg Infect Dis (2005) 11:1121-3. doi:10.3201/eid1107.040724

351. Bonnet S, Jouglin M, L'Hostis M, Chauvin A. Babesia sp. EU1 from roe deer and transmission within Ixodes ricinus. Emerg Infect Dis (2007) 13:1208-10. doi:10.3201/eid1308.061560

352. Becker CA, Bouju-Albert A, Jouglin M, Chauvin A, Malandrin L. Natural transmission of zoonotic Babesia spp. by Ixodes ricinus ticks. Emerg Infect Dis (2009) 15:320-2. doi:10.3201/eid1502.081247

353. Bonnet S, Brisseau N, Hermouet A, Jouglin M, Chauvin A. Experimental in vitro transmission of Babesia sp. (EU1) by Ixodes ricinus. Vet Res (2009) 40:21. doi:10.1051/vetres/2009004

354. Duh D, Petrovec M, Avsic-Zupanc T. Molecular characterization of human pathogen Babesia EU1 in Ixodes ricinus ticks from Slovenia. J Parasitol (2005) 91:463-5. doi:10.1645/GE-394R

355. Casati S, Sager H, Gern L, Piffaretti JC. Presence of potentially pathogenic Babesia sp. for human in Ixodes ricinus in Switzerland. Ann Agric Environ Med (2006) 13:65-70.

356. Wielinga PR, Fonville M, Sprong H, Gaasenbeek C, Borgsteede F, van der Giessen JW. Persistent detection of Babesia EU1 and Babesia microti in Ixodes ricinus in the Netherlands during a 5-year surveillance: 2003-2007. Vector Borne Zoonotic Dis (2009) 9:119-22. doi:10.1089/vbz.2008.0047

357. Cieniuch S, Stanczak J, Ruczaj A. The first detection of Babesia EU1 and Babesia canis canis in Ixodes ricinus ticks (Acari, Ixodidae) collected in urban and rural areas in northern Poland. Pol J Microbiol (2009) 58:231-6.

358. Cassini R, Bonoli C, Montarsi F, Tessarin C, Marcer F, Galuppi R. Detection of Babesia EU1 in Ixodes ricinus ticks in northern Italy. Vet Parasitol (2010) 171:151-4. doi:10.1016/j.vetpar.2010.03.009

359. Lempereur L, De Cat A, Caron Y, Madder M, Claerebout E, Saegerman C, et al. First molecular evidence of potentially zoonotic Babesia microti and Babesia sp. EU1 in Ixodes ricinus ticks in Belgium. Vector Borne Zoonotic Dis (2011) 11:125-30. doi:10.1089/vbz.2009.0189

360. Welc-Faleciak R, Bajer A, Paziewska-Harris A, Baumann-Popczyk A, Sinski E. Diversity of Babesia in Ixodes ricinus ticks in Poland. Adv Med Sci (2012) 57:364-9. doi:10.2478/v10039-012-0023-9

361. Lack JB, Reichard MV, Van Den Bussche RA. Phylogeny and evolution of the Piroplasmida as inferred from 18S rRNA sequences. Int J Parasitol (2012) 42(4):353-63. doi:10.1016/j.ijpara.2012.02.005

362. Schnittger L, Rodriguez AE, Florin-Christensen M, Morrison DA. Babesia: a world emerging. Infect Genet Evol (2013) 12(8):1788-809. doi:10.1016/j. meegid.2012.07.004

363. Cornillot E, Dassouli A, Garg A, Pachikara N, Randazzo S, Depoix D, et al. Whole genome mapping and re-organization of the nuclear and mitochondrial genomes of Babesia microti isolates. PLoS One (2013) 8(9):e72657. doi:10.1371/journal.pone.0072657

364. Foppa IM, Krause PJ, Spielman A, Goethert H, Gern L, Brand B, et al. Entomologic and serologic evidence of zoonotic transmission of Babesia microti, eastern Switzerland. Emerg Infect Dis (2002) 8:722-6. doi:10.3201/eid0807. 010459

365. Skotarczak B, Cichocka A. The occurrence DNA of Babesia microti in ticks Ixodes ricinus in the forest areas of Szczecin. Folia Biol (Krakow) (2001) 49:247-50.

366. Egyed L, Elő P, Sréter-Lancz Z, Széll Z, Balogh Z, Sréter T. Seasonal activity and tick-borne pathogen infection rates of Ixodes ricinus ticks in Hungary. Ticks Tick Borne Dis (2012) 3(2):90-4. doi:10.1016/j.ttbdis.2012.01.002

367. Duh D, Petrovec M, Avsic-Zupanc T. Diversity of Babesia infecting European sheep ticks (Ixodes ricinus). J Clin Microbiol (2001) 39:3395-7. doi:10.1128/ JCM.39.9.3395-3397.2001

368. Hartelt K, Oehme R, Frank H, Brockmann SO, Hassler D, Kimmig P. Pathogens and symbionts in ticks: prevalence of Anaplasma phagocytophilum (Ehrlichia sp.), Wolbachia sp., Rickettsia sp., and Babesia sp. in Southern Germany. Int J Med Microbiol (2004) 293(Suppl 37):86-92. doi:10.1016/S1433-1128(04) 80013-5

369. Nijhof AM, Bodaan C, Postigo M, Nieuwenhuijs H, Opsteegh M, Franssen L, et al. Ticks and associated pathogens collected from domestic animals in the Netherlands. Vector Borne Zoonotic Dis (2007) 7(4):585-95. doi:10.1089/vbz. 2007.0130

370. Cotte V, Bonnet S, Le Rhun D, Le Naour E, Chauvin A, Boulouis HJ, et al. Transmission of Bartonella henselae by Ixodes ricinus. Emerg Infect Dis (2008) 14(7):1074-80. doi:10.3201/eid1407.071110

371. Halos L, Jamal T, Maillard R, Beugnet F, Le Menach A, Boulouis HJ, et al. Evidence of Bartonella sp. in questing adult and nymphal Ixodes ricinus ticks from France and co-infection with Borrelia burgdorferi sensu lato and Babesia sp. Vet Res (2005) 36(1):79-87. doi:10.1051/vetres:2004052

372. Reis C, Cote M, Le Rhun D, Lecuelle B, Levin ML, Vayssier-Taussat M, et al. Vector competence of the tick Ixodes ricinus for transmission of Bartonella birtlesii. PLoS Negl Trop Dis (2011) 5(5):e1186. doi:10.1371/journal.pntd.0001186

373. Vayssier-Taussat M, Moutailler S, Michelet L, Devillers E, Bonnet S, Cheval J, et al. Next generation sequencing uncovers unexpected bacterial pathogens in ticks in western Europe. PLoS One (2013) 8(11):e81439. doi:10.1371/journal. pone.0081439

374. Angelakis E, Pulcini C, Waton J, Imbert P, Socolovschi C, Edouard S, et al. Scalp eschar and neck lymphadenopathy caused by Bartonella henselae after tick bite. Clin Infect Dis (2010) 50(4):549-51. doi:10.1086/650172

375. Platonov AE, Karan LS, Kolyasnikova NM, Makhneva NA, Toporkova MG, Maleev VV, et al. Humans infected with relapsing fever spirochete Borrelia miyamotoi, Russia. Emerg Infect Dis (2011) 17(10):1816-23. doi:10.3201/ eid1710.101474 
376. Krause PJ, Narasimhan S, Wormser GP, Rollend L, Fikrig E, Lepore T, et al. Human Borrelia miyamotoi infection in the United States. NEngl J Med (2013) 368(3):291-3. doi:10.1056/NEJMc1215469

377. Chowdri HR, Gugliotta JL, Berardi VP, Goethert HK, Molloy PJ, Sterling SL, et al. Borrelia miyamotoi infection presenting as human granulocytic anaplasmosis: a case report. Ann Intern Med (2013) 159(1):21-7. doi:10.7326/00034819-159-1-201307020-00005

378. Gugliotta JL, Goethert HK, Berardi VP, Telford SR III. Meningoencephalitis from Borrelia miyamotoi in an immunocompromised patient. $N$ Engl J Med (2013) 368(3):240-5. doi:10.1056/NEJMoa1209039

379. Hovius JW, de Wever B, Sohne M, Brouwer MC, Coumou J, Wagemakers A, et al. A case of meningoencephalitis by the relapsing fever spirochaete Borrelia miyamotoi in Europe. Lancet (2013) 382(9892):658. doi:10.1016/S01406736(13)61644-X

380. Cosson JF, Michelet L, Chotte J, Le Naour E, Cote M, Devillers E, et al. Genetic characterization of the human relapsing fever spirochete Borrelia miyamotoi in vectors and animal reservoirs of Lyme disease spirochetes in France. Parasit Vectors (2014) 7:233. doi:10.1186/1756-3305-7-233

381. McMullan LK, Folk SM, Kelly AJ, MacNeil A, Goldsmith CS, Metcalfe MG, et al. A new phlebovirus associated with severe febrile illness in Missouri. $N$ Engl J Med (2012) 367(9):834-41. doi:10.1056/NEJMoa1203378
Conflict of Interest Statement: The authors declare that the research was conducted in the absence of any commercial or financial relationships that could be construed as a potential conflict of interest.

Received: 11 August 2014; accepted: 09 November 2014; published online: 01 December 2014.

Citation: Rizzoli A, Silaghi C, Obiegala A, Rudolf I, Hubálek Z, Földvári G, Plantard O, Vayssier-Taussat M, Bonnet S, Špitalská E and Kazimírová M (2014) Ixodes ricinus and its transmitted pathogens in urban and peri-urban areas in Europe: new hazards and relevance for public health. Front. Public Health 2:251. doi: 10.3389/fpubh.2014.00251

This article was submitted to Epidemiology, a section of the journal Frontiers in Public Health.

Copyright (c) 2014 Rizzoli, Silaghi, Obiegala, Rudolf, Hubálek, Földvári, Plantard, Vayssier-Taussat, Bonnet, Špitalská and Kazimírová. This is an open-access article distributed under the terms of the Creative Commons Attribution License (CC BY). The use, distribution or reproduction in other forums is permitted, provided the original author(s) or licensor are credited and that the original publication in this journal is cited, in accordance with accepted academic practice. No use, distribution or reproduction is permitted which does not comply with these terms. 